Seyahat ve Otel İşletmeciliği Dergisi/

Journal of Travel and Hospitality Management

17(1), 2020, 103-123.

Gönderim Tarihi: 16.04.2019

Kabul Tarihi:20.02.2020

DOI: $10.24010 /$ soid. 554535

\title{
Turizm Dergilerinde Yayınlanan İnovasyon Başlıklı Makalelerin Bibliyometrik Profili
}

\section{Bibliometric Profile of Innovation Related Articles Published in Academic Tourism Journals}

Arş. Gör. Pembe ÜLKER

Erciyes Üniversitesi

Turizm Fakültesi

E-posta: pembeulker@erciyes.edu.tr
Arş. Gör. Nazlı ÖRNEK

Erciyes Üniversitesi

Turizm Fakültesi

E-posta: nazliornek@erciyes.edu.tr

\author{
Dr. Öğr. Üyesi Harun ÇALHAN \\ Erciyes Üniversitesi \\ Turizm Fakültesi \\ E-posta: hcalhan@erciyes.edu.tr
}

\begin{abstract}
Öz
Bu çalışmada, Türkçe yayın yapan akademik turizm dergilerinde yayınlanan inovasyon başlıkı makalelerin bibliyometrik profilinin belirlenmesi amaçlanmıştır. Çalışma kapsamında, zaman sınırlaması olmaksızın, belirlenen 30 akademik turizm dergisinin 1998-2019 yılı son sayıları dâhil olmak üzere bütün sayıları taranmış, başlığında "inovasyon", "yenilik", "yenileşim", "inovatif", "yenilikçi" ve "yenilikçilik" kelimelerinden en az biri bulunan ve erişilebilen 33 makale tespit edilmiştir. Makaleler yayın yılı, dergiler, konular, benimsenen araştırma deseni, örneklem büyüklüğü, veri toplama yöntemi, incelenen alanlar gibi bazı parametreler çerçevesinde değerlendirilmiş ve özelliklerine göre kategorize edilmiştir. Elde edilen bulgular inovasyon ile ilgili makalelerin akademik turizm dergilerinde 2008 yılı itibarıyla yayınlanmaya başladığı ve yayınlanma oranının 2014 yılı sonrasında artış gösterdiğine işaret etmektedir. Bunun yanı sıra inovasyon konulu makalelerin en çok sırasıyla "Journal of Tourism and Gastronomy Studies", "Uluslararası Turizm, Ekonomi ve İşletme Bilimleri Dergisi" ve "Seyahat ve Otel İşletmeciliği Dergisi"nde yayınlanmış olduğu tespit edilmiştir. Ayrıca, incelenen 33 makalede ağırıklı olarak nicel araştırma yönteminin benimsendiği ve yoğun olarak anket tekniği ile veri toplandığı araştırmanın önemli bulgularından bazıları olarak ifade edilebilir.
\end{abstract}

Anahtar Kelimeler: Bibliyometrik analiz, İnovasyon, Akademik Turizm Dergileri, Turizm.

\begin{abstract}
In this study, it was aimed to determine the bibliometric profile of Turkish articles published in academic tourism journals. Within the scope of the study, all the issues of the 30 academic tourism journals including the latest issues of 1998-2019, have been scanned without any time limitation and 33 articles were identified that are accessible and contained at least one of the words "innovation", "innovativeness", "innovative", and "innovator" in their headings. The articles were evaluated within the framework of some parameters such as publication year, journals, topics, research design adopted, sample size, data collection method, research areas and categorized according to their characteristics. The findings indicate that the articles about innovation started to be published in academic tourism journals as of 2008 and the rate of publication increased after the year 2014. In addition, it was determined that articles on innovation were published mostly in "Journal of Tourism and Gastronomy Studies", "International Journal of Tourism, Economics and Business Sciences" and "Journal of Travel and Hotel Management" respectively. Furthermore, some of the important findings of the research can be expressed as that the quantitative research method was adopted predominantly in 33 articles examined and data was collected mainly with the survey technique.
\end{abstract}

Key Words: Bibliometric Analysis, Innovation, Academic Tourism Journals, Tourism. 


\section{Giriş}

Sürekli artan rekabet içerisinde hem araştırmacılar hem de sektör temsilcileri inovasyonun gerekli olduğunu düşünmekte, inovasyona önem vermekte ve yönetim anlayışlarını inovasyona uygun hâle getirmektedirler (Kızılırmak ve Albayrak, 2013: 56). Diğer hizmet sektörlerine benzer şekilde, turizm sektöründe de turistlerin değişen demografik özelliklerinden kaynaklı yaşam tarzlarının farklılaşması ve turizmde taklit ürünlere yönelik görece düşük engeller olması nedeniyle turizm sektöründe önemli zorluklarla karşılaşılabilmektedir. Bu zorluklar ve değişimler, turizm işletmelerini ve turistik destinasyonları giderek artan rekabetçi ortamda pazardaki konumlarını koruyabilmeleri açısından inovasyon yapmaya mecbur bırakmaktadır (Presenza, Petruzelli ve Sheehan, 2019:192). Turizm sektöründe gerçekleşen inovasyon faaliyetlerinin turizm işletmelerine maliyetleri düşürmek, operasyonların verimliliğini ve/veya kâr seviyelerini arttırmak, tüketicilerin değişen intiyaçlarını karşılamada kolaylık sağlamak, arzın değişen talep yapılarına uyumunda esneklik sağlamak, rekabet avantajına sahip olmak ve rekabette uzun dönemli güçlü kalmaya yardımcı olmak gibi birçok yarar (Pırnar, Bulut ve Eriş, 2012:134) sağlamasından dolayı sürdürülebilir rekabet üstünlüğü ve yüksek işletme performansı elde etmede son derece önemli bir faktör olarak görülmektedir. Bununla birlikte, inovasyon sadece destinasyon içinde birbirleri ile rekabet eden turizm işletmeleri için değil aynı zamanda daha fazla ziyaretçi çekmeye çalışan ve birbirleri ile rekabet eden destinasyonlar içinde önemli bir güç olarak değerlendirilmektedir (Martínez-Pérez, Elche ve Garcia-Villaverde, 2019:81).

Alanyazında sektörle bağlantılı olarak oluşturulmuş akademik çalışmalar oldukça ilgi görmektedir. Buna yönelik temel varsayım, bilginin akademide yaratıldığı ve sonra daha da geliştirilmek ve işlenmek üzere işletmelere aktarıldığıdır. Nitekim yapılan çalışmalar, üniversite araştırmalarının iş başarısının gelişimi için önemli olduğunu ve etkisinin hafife alınmaması gerektiğini göstermektedir (Hjalager, 2002: 468-469). İnovasyonun turizm sektöründe çok önemli olduğu konusunda tüm araştırmacıların hemfikir olduğu (Peters ve Pikkemaat, 2005: 5) ifade edilse de yapılan birçok çalışmada (Hjalager, 1997; Peter ve Pikkemaat, 2005; Camisón ve Monfort-Mir, 2012; MartínezPérez, Elche ve Garcia-Villaverde, 2019: 82) inovasyon konusunda hala sınırlı sayıda ve yetersiz çalışmanın olduğu vurgulanmaktadır. Türkiye'de inovasyon konusunun çok fazla inceleme alanı olarak ele alınmadığı ve ulusal alanyazında inovasyon üzerine odaklanan oldukça sınırlı sayıda çalışma olduğu (Erdem, Gökdeniz ve Met, 2011:79) da belirtilmektedir.

Bibliyometrik analiz pek çok alanda uygulanabilmekte (Sánchez, Del Rio ve Garcia, 2017:9) ve sınırsız sayıda kaynak bu analiz aracılığıyla incelenebilmektedir (Wallin, 2005:261). Turizm alanının olgunluğunun ölçülmesi için hem niceliksel (bibliyometrik analiz gibi) hem de niteliksel (alanyazın taraması gibi) tekniklerle gerçekleştirilen araştırmaların gerekli olduğu ifade edilmektedir (Köseoğlu, Şehitoğlu ve Parnell, 2015:359). Turizmde farklı alanların niceliksel olarak bir değerlendirmesini yapmak üzere özellikle son yıllarda bibliyometrik analiz kullanan çalışma sayısı artış göstermiştir. Bu çalışmada ise akademik turizm dergilerinde, yıl sınırlandırması yapılmaksızın, dergilerin ilk basıldıkları yıllardan itibaren inovasyon başlıklı makalelerin bibliyometrik olarak değerlendirilmesi amaçlanmaktadır. Buradan hareketle akademik turizm dergilerinde Türkçe yayınlanmış inovasyon konusunda yapılmış çalışmalar bibliyometrik analiz ile incelenmiştir. Bu çalışmada a) İnovasyon konusunda akademik turizm dergilerinde Türkçe yayınlanmış çalışma sayısı nedir?, b) Çalışmaların konularına göre dağılımı nedir?, c) Çalışmaların turizm alt sektörlerine göre dağılımı nedir?, d) Çalışmaların yıllara göre dağılımı nedir?, e) Çalışmaların dergilere göre dağılımı nedir?, f) Çalışmaların türü nedir?, g) Çalışmalarda kaynak kullanım düzeyi nedir? gibi temel 
araştırma sorularına cevap aranmıştır. Bu çalışmanın ulusal alanyazında inovasyon konusunun ele alınma düzeyine yönelik bilgiler sunacağı ve ulusal alanyazınına katkı sağlayacağı düşünülmektedir.

\section{Literatür Taraması}

\subsection{Bibliyometrik Analiz}

Bibliyometri, matematiksel ve istatistiki yöntemlerin kitaplara ve diğer basılı kaynaklara uygulanması olarak ifade edilmektedir (Pritchard, 1969:349). Fairthorne (2005:171) bibliyometriyi basılı kaynakların ve kaynaklara dair özelliklerin niceliksel açıdan ele alınması olarak tanımlamaktadır. Bu yöntemin temel amacı somut olmayan nitelikleri somut ve dolayısıyla yönetilebilir hâle getirmek olarak ifade edilmektedir (Wallin, 2005: 261). Bibliyometrik çalışmalar, akademik alanyazını analiz etmek için istatistiki yöntemlerin kullanılmasını içermektedir (Ruhanen, Weiler, Moyle ve Mclennon, 2015). Bibliyometrik yöntemler doğası gereği niceldir, ancak yazılı kaynakların nitel özellikleri hakkında bilgi vermek amacıyla kullanılırlar (Wallin, 2005:261). Bilimsel bilginin birikimsel olması, her yeni araştırmanın kendinden öncekileri temel alarak gerçekleşmesi ve alandaki bilgiyi zenginleştirmesi beklenmektedir (Sánchez, Del Rio ve Garcia, 2017: 9). Bu doğrultuda bibliyometrik analiz de daha önce bir alanda yapılan çalışmaların sayısal olarak tarif edilmesi, alanın ne ölçüde doygunluğa ulaştığının resminin çizilmesi ve alandaki eğilimin hangi yöne doğru evrildiğinin anlaşılması için son dönemlerde sıklıkla kullanılmaktadır.

Günümüzde bibliyometri, neredeyse tüm bilim alanlarında kullanılan ender analiz yöntemlerinden biridir (Glanzel, 2003: 5). Bibliyometri hem genel olarak hem de turizm özelinde popüler hâle gelmiş araştırmacılar, kurumlar, dergiler ve disiplinler nezdinde bibliyometrik çalışmaların önemine dair farkındalık artmıştır (Evren ve Kozak, 2014). Turizmde yayın yapan araştırmacı sayısının ve dolayısıyla yayın sayısının artması ve turizmin bir bilim alanı olarak büyümesi ile birlikte bu alandaki bibliyometrik çalışmaların sayısında da artış gözlendiği ifade edilmektedir (Özel ve Kozak, 2012: 716).

Uluslararası turizm alanyazınında bibliyometri sıklıkla kullanılan yöntemlerden biridir. Örneğin, turizmde iş etiği (Köseoğlu, Şehitoğlu, Ross ve Parnell, 2016), sürdürülebilirlik (Ruhanen vd., 2015; Niñerola, Sánchez-Rebull ve Hernandez-Lara, 2019), şarap turizmi (Sánchez, Del Rio ve Garcia, 2017), macera turizmi (Cheng, Edwards, Darcy ve Redfern, 2018), araştırma yöntemleri (Koç ve Boz, 2014) ve turizm çalışmalarında istatistiki yöntemlerin kullanımı (Palmer, Sese ve Montano, 2005) konularında bibliyometrik çalışmaların yapıldığı görülmektedir.

Türk turizm alanyazınında bibliyometriyi yöntem olarak benimseyen ilk çalışmalar 1990’lı yıllarda gerçekleştirilmiştir (Kozak, 1994; Kozak, 1995; Kozak ve İçöz, 1999). Daha sonra turizmin pek çok alanında gerçekleşen çalışmalar ile turizm alanında gerçekleştirilen çalışmalara dair sayısal bilgilerin elde edilmesi mümkün hâle gelmiştir. İlgili alanyazın incelendiğinde daha önceki yıllarda kırsal turizm (Bozok, Kılıç ve Özdemir, 2017), turizm pazarlaması (Özel ve Kozak, 2012), sağlık turizmi (Temizkan, Çiçek ve Özdemir, 2015), turist rehberliği (Şahin ve Acun, 2015), turizm ve girişimcilik (Işık vd., 2019) konularında yayınlanan makalelerde ve turizm ve gastronomi alanlarında yazılan tezler (Cevizkaya, İlsay ve Avcıkurt, 2014; Tayfun, Küçükergin, Aysen, Eren ve Özekici, 2016; Demirbulat ve Dinç, 2017; Aydın, 2017; Sünnetçioğlu, Yalçınkaya, Olcay ve Mercan, 2017; Tayfun, Ülker, Gökçe, Tengilimoğlu, Sürücü ve Durmaz, 2018; Ayaz ve Türkmen, 2018) ile turizm alanında yayınlanan bildirilerde (Yılmaz, 2017; Şahin ve Acun, 2015; Çakıcı, Yıldırım ve Karacaoğlu, 2013) bibliyometriden yoğun olarak 
faydalanıldığı görülmektedir. Bunun yanı sıra, bibliyometri ile tek bir dergide yayınlanan çalışmalar incelenebildiği gibi (Kozak, 1994; Karagöz ve Kozak, 2014; Çiçek ve Kozak, 2012), birden fazla dergide yayınlanan çalışmalar da incelenebilmektedir (Evren ve Kozak, 2014; Köseoğlu, Şehitoğlu ve Parnell, 2015).

\section{2. İnovasyon}

Günümüz ekonomisinin en önemli sloganlarından biri artık "ya inovasyon yap ya da öl" olarak ifade edilmektedir (Lemon ve Sahota, 2004: 483) ki bunu doğrular şekilde inovasyon, tüketicilerin dünyanın her yerinden ürün ve hizmet seçimi yaptığı ve belli oranlarda doyuma ulaşmış her sektör için önemli bir var olma stratejisi olarak görülmektedir (Peters ve Pikkemaat, 2005: 1). Küresel rekabet şartlarında hem mevcut işletmelerin hem de yeni kurulan işletmelerin büyümesi ve varlığını sürdürebilmesi, inovasyon yapmalarına ve inovatif olmalarına dayanmaktadır. Artan rekabet ve değişen tüketici beklentileri sonucunda işletmeler pazardaki rekabetçi yapılarını sürdürebilmek için ürün veya süreçlerinde birtakım yenilikler yapmak mecburiyetinde kalmıştır (Işık ve Keskin, 2013: 44). İnovatif ve yaratıcı düşünce ile beslenen işletmelerin başarılı olma şansının çok daha yüksek olduğu ancak inovasyonu içselleştirememiş ve aktif kullanamayan işletmelerin ayakta kalmasının pek de mümkün olmadığı vurgulanmaktadır (Çiftçi, Tozlu ve Akçay, 2014: 77).

Örgütlerin temel yapı taşı olan bireylerin yenilikçiliği ise, yeni bir fiziksel ürün, hizmet ya da fikrin birey tarafından benimsenmesi ve bireyin bunu uygulama yeteneği olarak ifade edilmektedir (Işık ve Türkmendağ, 2016: 70). İnovasyon hizmet endüstrisinde artan bir öneme ve role sahip olmakla birlikte tartışmasız özellikle turizm sektörü için de çok önemli bir faktör konumuna gelmiştir (Aldebert, Dang ve Longhi, 2011: 1204). İnovasyon, turizm endüstrisinde özellikle destinasyon rekabetçiliği ve turizm işletmelerinin rekabet üstünlüğü elde etmesinde kritik bir faktör olduğunun anlaşılmasından sonra (Martínez-Pérez, Elche ve Garcia-Villaverde, 2019: 82) ve performans üzerindeki etkisinin hala tartışılıyor olmasından (Martin-Rios ve Ciobanu, 2019: 218) dolayı akademisyenlerin, ekonomistlerin ve politikacıların ilgisini çekmeye devam etmektedir.

Türkçe'de "inovasyon", "yenilik", "yenilenme" ve "yenileşim" kelimeleri ile ifade edilen inovasyon kavramı, etimolojik olarak Latince kökene dayanmakta olup, "innovare" kelimesinden türetilmiştir. Yeni bir şey yapmak anlamına gelen (Tidd, Bessant ve Pavitt, 2005: 66) inovasyon kavramı, ilk kez Joseph Schumpeter tarafından orijinali 1912 yılında Almanca yayınlanan ve 1934 yılında İngilizceye çevrilen "Ekonomik Kalkınma Teorisi" adlı çalışmada ele alınmıştır (Schumpeter, 2003). Schumpeter (2003)'e göre inovasyon ile icat birbirinden tamamen farklı iki kavramdır ve kalkınmanın itici gücü icatlar değil inovasyonlardır. Nitekim, inovasyona dönüşemeyen icadın ekonomik değerinin bulunmadığını ve ekonomik kalkınmada öneminin olmadığını ifade etmektedir (Demir, 1995: 162). Schumpeter, ekonomik kalkınmanın ancak eskilerin yerini alan yeni teknolojileri kapsayan dinamik bir süreç olan "inovasyon" yoluyla başarılabileceğini savunmakta ve yarattıkları etkileri bakımından inovasyonları büyük dengeleri değiştirebilen değişimler yaratan "radikal inovasyonlar" ve değişim sürecinde sürekli gelişen "artımsal inovasyonlar" olarak sınıflandırmaktadır (Çalhan, 2018: 549). Türk Dil Kurumu (2019) inovasyon kelimesini, "yenileşim" olarak çevirmekte ve "değişen koşullara uyabilmek için toplumsal, kültürel ve yönetimsel ortamlarda yeni yöntemlerin kullanılmaya başlanması, yenilik, inovasyon" olarak ifade etmektedir. Ekonomik İşbirliği ve Kalkınma Örgütü (OECD) tarafından 2005 yılında yayınlanan Oslo Kılavuzu'nda inovasyon kavramı; yeni veya önemli ölçüde geliştirilmiş ürün, süreç, pazarlama yöntemi ve/veya örgütsel yöntemin uygulanması şeklinde tanımlamaktadır. Bir başka kaynakta 
ise, inovasyon, var olan fiziksel ürün, süreç veya hizmetleri geliştirmeye ve iyileştirmeye yönelik yenilikçi fikirler üretmek olarak ifade edilmektedir (Işık ve Barlak, 2018: 16). En genel şekliyle inovasyon bir birey, bir grup insan, bir işletme, bir sanayi sektörü veya bir bütün olarak bir toplum için yeni olduğu düşünülen bir fikir, ürün veya süreç, bir sistem veya cihaz olarak tanımlanabilmektedir (Halpern, 2010: 52).

Inovasyonlar; (a) tüketicinin daha önce tanımadığı yeni bir malın ya da bir malın yeni bir tipinin veya aynı malın yeni bir kalitesinin pazara sunulması, (b) üretime yönelik yeni bir tekniğin uygulanması, (c) yeni pazarların keşfi veya yaratılması, (d) yeni bir hammadde veya yan mamul madde kaynağının bulunması ve (e) endüstrinin yeniden organize edilmesi olarak sınıflandırılmaktadır (Schumpeter, 1964'ten aktaran Demir, 1995: 163). OECD, Oslo Kılavuzu'nda inovasyonların sınıflandırılmasına yönelik ortak bir kavramsal çerçevenin oluşturulmasının gerekliliğinden hareketle inovasyonları ürün, süreç, pazarlama ve örgütsel inovasyonlar şeklinde sınıflandırmaktadır. Turizm sektöründe inovasyon üzerine yapılan birçok çalışmada da (Hjalager, 1997; Ottenbacher ve Gnoth, 2005; Hjalager, 2010; Pivcevic ve Pranicevic, 2012; Vila, Enz ve Costa, 2012; Nordli, 2018; Martin-Rios ve Ciobanu, 2019) OECD (2005) tarafından yapılan inovasyon sınıflandırmasının aynısının veya benzer sınıflandırmaların ele alındığı görülmektedir. Ürün (mal ve hizmet) inovasyonu tüketici, işletme veya destinasyon için daha önce görülmemiş yeni olarak kabul edilen değişiklikler şeklinde ifade edilmektedir (Hjalager, 2010: 2). Süreç inovasyonu, hizmet üretimi ve teslimat süreçlerine yönelik yapılan inovasyonlar veya iyileştirmeler olarak ifade edilirken (Jacob, Tintoré, Aguilo, Bravo ve Mulet, 2003: 282) pazarlama inovasyonu, işletmelerin potansiyel veya mevcut müşterilere mal ve hizmetlerini pazarlamada yeni yöntemler geliştirmesi şeklinde ifade edilmektedir (Halpern, 2010: 52). Örgütsel inovasyon ise, bir işletmenin ticari uygulamalarında, işyeri organizasyonunda veya dış ilişkilerinde yeni bir örgütsel yöntemi uygulaması şeklinde açıklanmaktadır (OECD, 2005: 55).

\section{Yöntem}

Bu çalışmada, Türkçe yayın yapan akademik turizm dergilerinde yayınlanan inovasyon konulu makalelerin profilinin belirlenmesi amaçlanmış ve bu doğrultuda bibliyometrik analizden yararlanımıştır. Bibliyometrik analiz, çeşitli parametreler (konular, yöntemler ve referanslar gibi) çerçevesinde makalelerin frekans ve alıntı analizini içeren bir tür içerik analizidir (Evren ve Kozak, 2014: 67). Bu bağlamda, bu çalışmanın nitel araştırma yöntemlerinden doküman incelemesi ve tür olarak da bibliyometrik inceleme şeklinde gerçekleştirildiği söylenebilir.

\subsection{Araştırma Soruları}

Bu çalışmada aşağıda yer alan araştırma sorularına yanıt aranmıştır:

a) İnovasyon ile ilgili makaleler dergilere, yıllara ve yazarların çalıştıkları kurumlara göre nasıl bir dağılım göstermektedir?

b) İnovasyon ile ilgili makaleler konularına, araştırma yaklaşımlarına, araştırma desenlerine ve incelediği alt sektörlere göre nasıl bir dağılım göstermektedir?

c) İnovasyon ile ilgili makaleler veri toplama yöntemlerine, örneklem büyüklüklerine, örneklem bölgelerine, analiz yöntemlerine ve kaynak sayılarına göre nasıl bir dağılım göstermektedir?

\subsection{Evren ve Örneklem}

Araştırmanın evreni, Türkçe yayın yapan akademik turizm dergilerinde yayınlanan inovasyon başlıklı makalelerden oluşmaktadır. Araştırma kapsamında bibliyometrik 
analize dahil edilecek makalelerin belirlenebilmesi için öncelikle, ULAKBİM ve Dergi Park üzerinden "turizm", "seyahat" ve "gastronomi" arama kelimeleriyle 23 akademik turizm dergisi ve Google Akademik üzerinden ilave 7 dergi daha olmak üzere doğrudan turizmle ilgili toplam 30 akademik turizm dergisi seçilmiştir. Taranan dergiler sadece akademik turizm dergileri ile sınırlı tutulmuş olup, enstitü dergileri gibi dergiler araştırma kapsamına alınmamıştır. Söz konusu dergilerin internet üzerinden ulaşılabilen cilt ve sayılarının 1998-2019 yılları arasını kapsadığı tespit edilmiştir. Dergiler ilk yayın yaptıkları yıldan itibaren taranmıştır. Araştırma kapsamında belirlenen akademik turizm dergilerine ilişkin liste Tablo 1'de sunulmuştur.

Tablo 1: İncelenen Akademik Turizm Dergileri

\begin{tabular}{|c|c|}
\hline Turizm Dergileri & $\begin{array}{l}\text { İncelenen Yayın } \\
\text { Aralığı }\end{array}$ \\
\hline Anatolia: Turizm Araştırmaları Dergisi & $2005-2019$ \\
\hline $\begin{array}{l}\text { Ankara Üniversitesi Beypazarı Meslek Yüksekokulu Turizm } \\
\text { Çalışmaları Dergisi }\end{array}$ & $2019-2019$ \\
\hline Aydın Gastronomy & 2017-2019 \\
\hline Çatalhöyük Uluslararası Turizm ve Sosyal Araştırmalar Dergisi & 2016-2019 \\
\hline Disiplinler Arası Akademik Turizm Dergisi & 2016-2019 \\
\hline Gastroia: Journal of Gastronomy and Travel Research & 2017-2019 \\
\hline Gazi Üniversitesi Ticaret ve Turizm Eğitim Fakültesi Dergisi & 1998-2019 \\
\hline $\begin{array}{l}\text { GSI Journals Serie a: Advancements in Tourism, Recreation and } \\
\text { Sport Sciences }\end{array}$ & 2018-2019 \\
\hline Güncel Turizm Araştırmaları Dergisi & 2017-2019 \\
\hline Journal of Gastronomy, Hospitality and Travel & 2018-2019 \\
\hline Journal of Hospitality and Tourism Issues & 2019-2019 \\
\hline Journal of Recreation and Tourism Research & 2014-2019 \\
\hline Journal of Tourism \& Gastronomy Studies & 2013-2019 \\
\hline Journal of Tourism Theory and Research & 2015-2019 \\
\hline Journal of Tourism Intelligence and Smartness & 2018-2019 \\
\hline Safran Kültür ve Turizm Äraştırmaları Dergisi & 2018-2019 \\
\hline Seyahat ve Otel İşletmeciliği Dergisi & 2004-2019 \\
\hline Sivas Interdisipliner Turizm Araştırmaları Dergisi & 2018-2019 \\
\hline Tourism and Recreation & 2019-2019 \\
\hline Turizm \& Araştırma Dergisi & 2012-2019 \\
\hline Turizm Araştırma Enstitüsü Dergisi & 2019-2019 \\
\hline Turizm Akademik Dergisi & 2014-2019 \\
\hline Turizm, Ekonomi ve İşletme Araştırmaları Dergisi & 2019-2019 \\
\hline Turist Rehberliği Dergisi & 2018-2019 \\
\hline Türk Turizm Araştırmaları Dergisi & 2017-2019 \\
\hline Uluslararası Global Turizm Araştırmaları Dergisi & 2017-2019 \\
\hline Uluslararası Güncel Turizm Araştırmaları Dergisi & 2017-2019 \\
\hline Uluslararası Kırsal Turizm ve Kalkınma Dergisi & 2017-2019 \\
\hline Uluslararası Turizm, Ekonomi ve İşletme Bilimleri Dergisi & 2017-2019 \\
\hline Uluslararası Türk Dünyası Turizm Araştırmaları Dergisi & 2016-2019 \\
\hline
\end{tabular}

\subsection{Veri Toplama Aracı ve Süreci}

Belirlenen 30 derginin tüm ciltleri ve sayılarında yer alan makalelerin başlıkları sistematik bir biçimde "inovasyon", "yenilik", "yenileşim", "inovatif", "yenilikçi" ve "yenilikçilik" kelimelerini içermesi çerçevesinde taranmış ve doğrudan inovasyon ile ilgili yayınlanmış toplam 33 makale tespit edilmiştir. Söz konusu dergilerde makale tarama işlemi internet üzerinden 01.12.2018-15.01.2020 tarihleri arasında yapılmış ve tüm dergilerin ilk cilt ve sayılarından başlanarak 2019 yılı son sayılarını kapsayacak şekilde tarama işlemine devam edilmiştir. Çevrimiçi olarak erişilebilen 33 makalenin tümü indirilmek suretiyle 
çalışma kapsamında incelemeye alınmıştır. Çalışmanın amacı doğrultusunda, 33 makalenin bibliyometrik profilini ortaya çıkarmak için farklı parametreler belirlenmiş ve makaleler bu parametreler çerçevesinde incelenmiştir. Parametreler oluşturulurken, daha önce turizm alanyazınında bibliyometrik analiz gerçekleştiren araştırmalarda (Şahin ve Acun, 2015; Yılmaz, 2017, Tayfun vd., 2018) kullanılan parametrelerden de faydalanılmıştır. Bu çalışmada belirlenen parametreler şunlardır;

- Yayın yılı

- Yayınlandığı dergi

- Yazarların çalıştıkları kurumlar

- Incelenen konu

- Araştırma yaklaşımı

- Araştırma deseni

- Örneklem bölgesi

- Örneklem büyüklüğü
- Veri toplama yöntemi

- Incelenen alt sektör

- Verinin toplandığı kitle

- Veri analiz yöntemi

- Türkçe kaynak sayısı

- Yabancı kaynak sayısı

- Toplam kaynak sayısı

\subsection{Geçerlilik ve Güvenilirlik}

Nitel araştırmaların geçerliliğini ortaya koymak için araştırmacının veri toplama aşamasına kendisinin dahil olması, araştırma yöntemi ve veri analiz süreci ile ilgili detaylı bilgilerin sunulması, parametrelerin belirlenmesi sürecinde araştırmacılar arasında tartışmaların yapılması, doküman incelemenin en az iki farklı araştırmacı tarafından yapılması (Yılmaz, 2017: 176), ham verinin ortaya çıkan kavramlara göre yeniden düzenlenmiş bir biçimde okuyucuya yorum katmadan ve verinin doğasına sadık kalınarak ayrıntıı bir şekilde aktarılması (Yıldırım ve Şimşek, 2008: 270) gerektiği dile getirilmektedir. Bu çalışmada, araştırmanın hangi aşamalarda ve nasıl gerçekleştirildiği açıkça ortaya konulmuştur. Araştırmanın yöntemi, evren ve örneklemi, veri toplama aracı ve süreci, veri analiz yöntemi, veri analizi süreci ve bulguları sunulmaya çalışılmıştır. Çalışmada araştırmacıların ortak uzlaşısı ile parametreler geliştirilmiş, aynı parametreler kullanılarak ayrı ayrı makale inceleme işlemi yapılmıştır. Çalışmanın her aşamasında araştırmacılar arası tartışmalar ve uzlaşı arayışı gerçekleştirilmek suretiyle araştırma geçerliliği sağlanmaya çalışılmıştır.

Araştırmanın güvenirliğinin sağlanması amacıyla "araştırmacı üçgenleme yöntemi" kullanılarak makaleler incelenmiş ve üç araştırmacı tarafından analiz edilerek yorumlanmıştır. Araştırmacı üçgenleme yöntemi, verilerin toplanması, analizi ve yorumlanmasında birden fazla araştırmacının yer almasını içeren nitel araştırmalarda kullanılan bir güvenilirlik yöntemidir (Başkale, 2016: 25). Makalelerin incelenmesi işlemi, araştırmacılar tarafından dört aşamada gerçekleştirilmiştir. İlk aşamada her araştırmacı tüm makaleleri bireysel olarak inceleyerek kendi verisini oluşturmuştur. İkinci aşamada değişim esasına dayalı olarak her bir araştırmacının oluşturduğu verinin doğruluğu diğer bir araştırmacı tarafından tekrar incelenerek kontrol edilmiştir. Üçüncü aşamada makalelerin tümü üç araştırmacının bir araya gelmesiyle tartışma ve uzlaşı esasına dayalı olarak tekrar kontrol edilmiştir. Dördüncü aşamada, söz konusu kontrollerde ortaya çıkan görüş farklılıkları tekrar değerlendirilmiş ve uzlaşı ile giderilmeye çalışıımıştır. Bu sayede çalışmanın güvenilirliği sağlanmaya çalışıımıştır.

\section{Bulgular}

Akademik turizm dergilerinde inovasyon ile ilgili makalelerin yayınlandığı yıllar incelendiğinde (Grafik 1), makalelerin 2008 yılı itibariyle yayınlanmaya başladığı görülmektedir. 2014 yılı sonrasında inovasyon konusundaki makalelerin dergilerde 
yayınlanma sayısının artış gösterdiği, 2014 öncesi yıllarda ise az sayıda makalenin yayınlanmış olduğu ifade edilebilir.

\section{Grafik 1: Makalelerin Yıllara Göre Dağılımı}

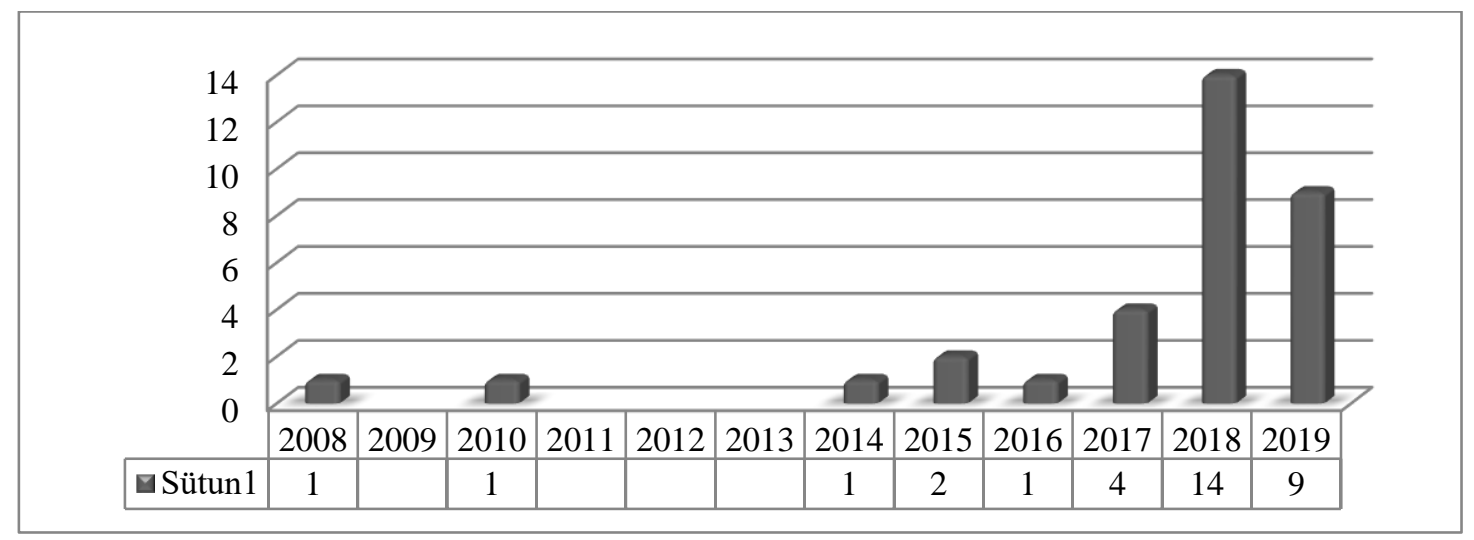

Grafik 1'de görüldüğü üzere, özellikle son üç yılda inovasyon konusunda yayınlanan makale sayısında dikkat çekici şekilde bir artış yaşanmıştır. Bu durum, özellikle 2010 yılından sonra turizm alanında yayın yapan akademik turizm dergi sayısının artmasına bağlı olarak inovasyon konusunda yayınlanan makale sayısının da artması ve daha da önemlisi inovasyon konusunun diğer pek çok sektör gibi turizm sektörü için de her geçen gün daha da önemli ve araştırılması gereken bir konu haline gelmesi ile açıklanabilir.

Inovasyon ile ilgili 33 makalenin yayınlandığı dergiler incelendiğinde (Grafik 2), en fazla makalenin "Journal of Tourism and Gastronomy Studies (JOTAGS)", "Uluslararası Turizm, Ekonomi ve İşletme Bilimleri Dergisi" ve "Seyahat ve Otel İşletmeciliği Dergisi (SOIDD)"nde yayınlandığı görülmektedir. JOTAGS yedi yıldır yayınlanmakta olan bir dergidir. Diğer dergilerle kıyaslandığında daha uzun süredir yayın yaptığı belirtilebilir. Bu açıdan incelendiğinde, bu alanda daha fazla makalenin yayınlanmış olması beklenen bir sonuçtur. Diğer taraftan, Uluslararası Turizm, Ekonomi ve İşletme Bilimleri Dergisi henüz üç yıldır yayınlanmakta olan bir dergi olmasına rağmen diğer dergilere kıyasla daha fazla sayıda inovasyon konusunda çalışma yayınlamıştır. Bu durum ise, her bir sayısında çok sayıda makaleye yer verilmesi ile açıklanabilir. Daha uzun süre yayın hayatı olan Anatolia: Turizm Araştırmaları Dergisi ve SOID dergilerinde ise nispeten daha az sayıda inovasyon alanında makale yayınlandığı görülmektedir. $\mathrm{Bu}$ durum, turizm akademisyenlerinin özellikle son yıllarda inovasyon konusunda çalışmalar yapmaya yöneldikleri veya geçmişte inovasyon ile ilgili yaptıkları çalışmalarının yayınlanmasında turizm dergilerini tercih etmemiş oldukları, başka dergilerde makalelerini yayınlatmış oldukları şeklinde yorumlanabilir. 


\section{Grafik 2: Makalelerin Dergilere Göre Dağılımı}

Gazi Üniversitesi Ticaret ve Turizm Eğitim.

Gastroia: Journal of Gastronomy and Travel.

Turizm \& Araştırma Dergisi

Journal of Recreation and Tourism Research

Güncel Turizm Araştırmaları Dergisi

Turizm Akademik Dergisi

Journal of Tourism Theory and Research

Türk Turizm Araştırmaları Dergisi

Anatolia: Turizm Araştırmaları Dergisi Journal of Tourism Intelligence and Smartness

Seyahat ve Otel İşletmeciliği Dergisi

Uluslararası Turizm, Ekonomi ve İşletme.

Journal of Tourism \& Gastronomy Studies

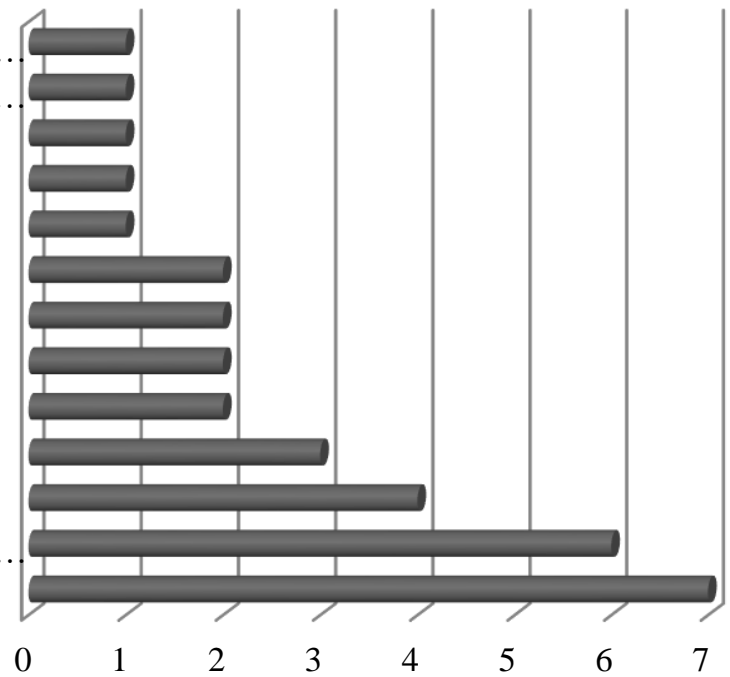

İncelenen 33 makalenin biri yedi yazar, biri dört yazar, üçü üç yazar, 16'sı iki yazar ve ikisi de bir yazar tarafından gerçekleştirilmiştir. Yazarların çalıştıkları kurumlara göre dağılımına bakıldığında sırasıyla Atatürk Üniversitesi, Mersin Üniversitesi, Muğla Sıtkı Koçman Üniversitesi, Çankırı Karatekin Üniversitesi, İstanbul Gelişim Üniversitesi, Kocaeli Üniversitesi, Gaziantep Üniversitesi ve Nevşehir Hacı Bektaş Veli Üniversitesi'nden araştırmacıların inovasyon konusunda makale yayınladığı görülmektedir. Diğer yazar sayıları ve yazarların çalıştıkları kurumlar Tablo 2'de sunulmaktadır.

Tablo 2: Yazarların Çalıştıkları Kurumlara Göre Dağılımı

\begin{tabular}{lc}
\hline Kurum Adı & Yazar Sayısı \\
\hline Atatürk Üniversitesi & 11 \\
Mersin Üniversitesi & 8 \\
\hline Muğla Sıtkı Koçman Üniversitesi & 7 \\
Çankırı Karatekin Üniversitesi & 6 \\
\hline İstanbul Gelişim Üniversitesi & 3 \\
\hline Kocaeli Üniversitesi & 3 \\
Gaziantep Üniversitesi & 3 \\
Nevşehir Hacı Bektaş Veli Üniversitesi & 3 \\
\hline Dokuz Eylül Üniversitesi & 2 \\
\hline Uluslararası Rekabet Araştırmaları Kurumu & 2 \\
\hline Balıkesir Üniversitesi & 2 \\
Karabük Üniversitesi & 2 \\
\hline Akdeniz Üniversitesi & 2 \\
\hline Sakarya Üniversitesi & 2 \\
\hline Gümüşhane Üniversitesi & 2 \\
Adana Bilim ve Teknoloji Üniversitesi & 1 \\
Kütahya Dumlupınar Üniversitesi & 1 \\
İstanbul Arel Üniversitesi & 1 \\
\hline Eskişehir Osman Gazi Üniversitesi & 1 \\
İzmir Kâtip Çelebi Üniversitesi & 1 \\
\hline Kahramanmaraş Sütçü Imam Üniversitesi & 1 \\
\hline Pamukkale Üniversitesi & 1 \\
\hline Recep Tayyip Erdoğan Üniversitesi & 1 \\
\hline
\end{tabular}


Tablo 2'nin devamı

\begin{tabular}{lc}
\hline Siirt Üniversitesi & $\mathbf{1}$ \\
\hline Süleyman Demirel Üniversitesi & 1 \\
Türk Hava Kurumu Üniversitesi & 1 \\
Bülent Ecevit Üniversitesi & 1 \\
Çukurova Üniversitesi & 1 \\
Isparta Uygulamalı Bilimler Üniversitesi & 1 \\
Kırklareli Unniversitesi & 1 \\
Zübeyde Hanım Lisesi & 1 \\
\hline
\end{tabular}

Makaleler konularına göre ele alındığında, ağırlıklı olarak "inovasyon uygulamaları" ve "bireysel yenilikçilik" konularında çalışmalar yapıldığı görülmektedir (Grafik 3). Bunun yanı sıra, "yenilik yönetimi", "ürün inovasyonu" ve "turizm ve inovasyon" konularında da kayda değer sayıda çalışma gerçekleştirildiği ifade edilebilir. Son olarak, "yönetsel inovasyon" ve "hizmet inovasyonu" konularında diğer konulara kıyasla daha az sayıda çalışma gerçekleştirildiği Grafik 3’te gösterilmektedir.

\section{Grafik 3: Makalelerin Konulara Göre Dağılımı}

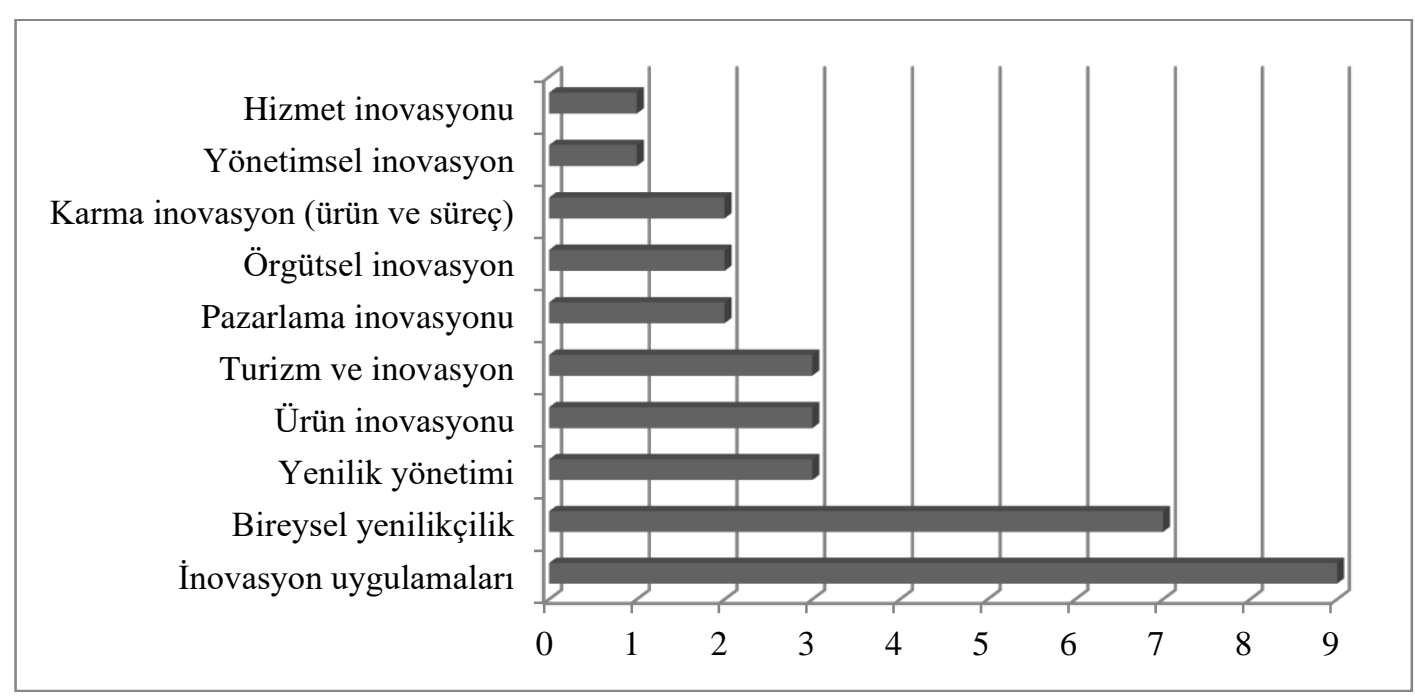

Makalelerin büyük çoğunluğunun nicel araştırma teknikleri kullanılarak gerçekleştirildiği görülmektedir (Grafik 4). Turizm ile ilgili araştırmalarda sağladığı bazı avantajlardan dolayı nicel tekniklerin sıklıkla kullanıldığı bilinmektedir. Ancak nitel tekniklerin de konu ile ilgili daha derinlemesine bilgi sağlamasından dolayı tercih edilmesi gerektiği de ifade edilmektedir. Bu çalışmanın sonuçları ile benzer nitelikte, turizm alanında gerçekleştirilen bazı bibliyometrik çalışmalarda (Aydın, 2017; Demirbulat ve Dinç, 2017; Sünnetçioğlu vd., 2017) genellikle nicel tekniklerin daha sıklıkla kullanıldığı sonucuna ulaşılmıştır. Bununla birlikte, son 20 yılda turizm alanında nitel tekniklerin de prestij kazandığı belirtilmektedir (Walle, 1997: 526). Bununla doğru orantılı olarak turizm dergilerinde de inovasyon konusunda nitel teknikler ile gerçekleştirilen makalelerin sayısının artış gösterdiği söylenebilir. İncelenen 33 makaleden alanyazın taraması, çeviri, kavramsal çalışma ve deneysel çalışma türündeki çalışmalar ise uygun olmayan olarak kodlanmıştır. 
Grafik 4: Makalelerin Benimsenen Araştırma Desenine Göre Dağılımı

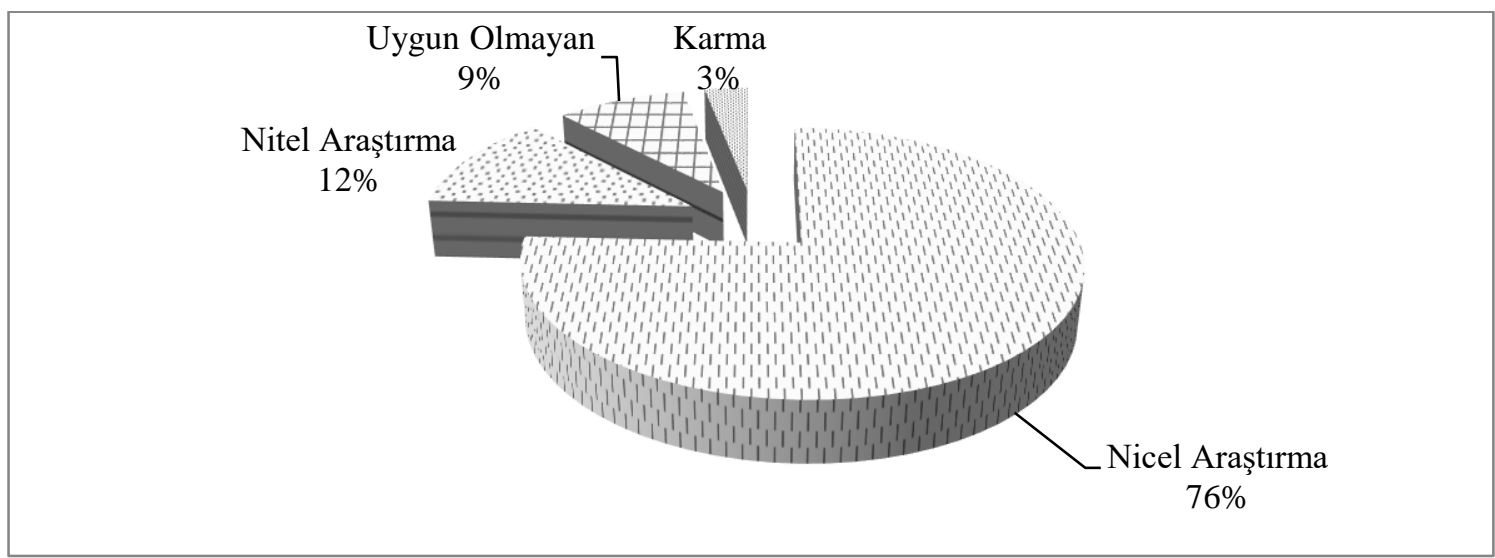

Grafik 5 incelendiğinde, makalelerin büyük kısmının Marmara Bölgesi'nden veri toplanmak suretiyle gerçekleştirildiği görülmektedir. Dört makale, iki ve daha fazla bölgeden veri toplanması suretiyle yapılmış olduğundan bu makaleler çoklu bölge olarak sınıflandırılmıştır. Dört makale Ege Bölgesi'nden, dört makale de Akdeniz Bölgesi'nden veri toplanarak gerçekleştirilmiştir. Üç makalede İç Anadolu Bölgesi araştırma alanı olarak seçilmiştir. Üç makalenin araştırma alanı tüm Türkiye olarak belirlenmiştir. Daha sınırlı sayıda çalışma ise Karadeniz Bölgesi, Doğu Anadolu Bölgesi ve yurtdışında gerçekleştirilmiştir.

\section{Grafik 5: Makalelerin Örneklem Bölgelerine Göre Dağılımı}

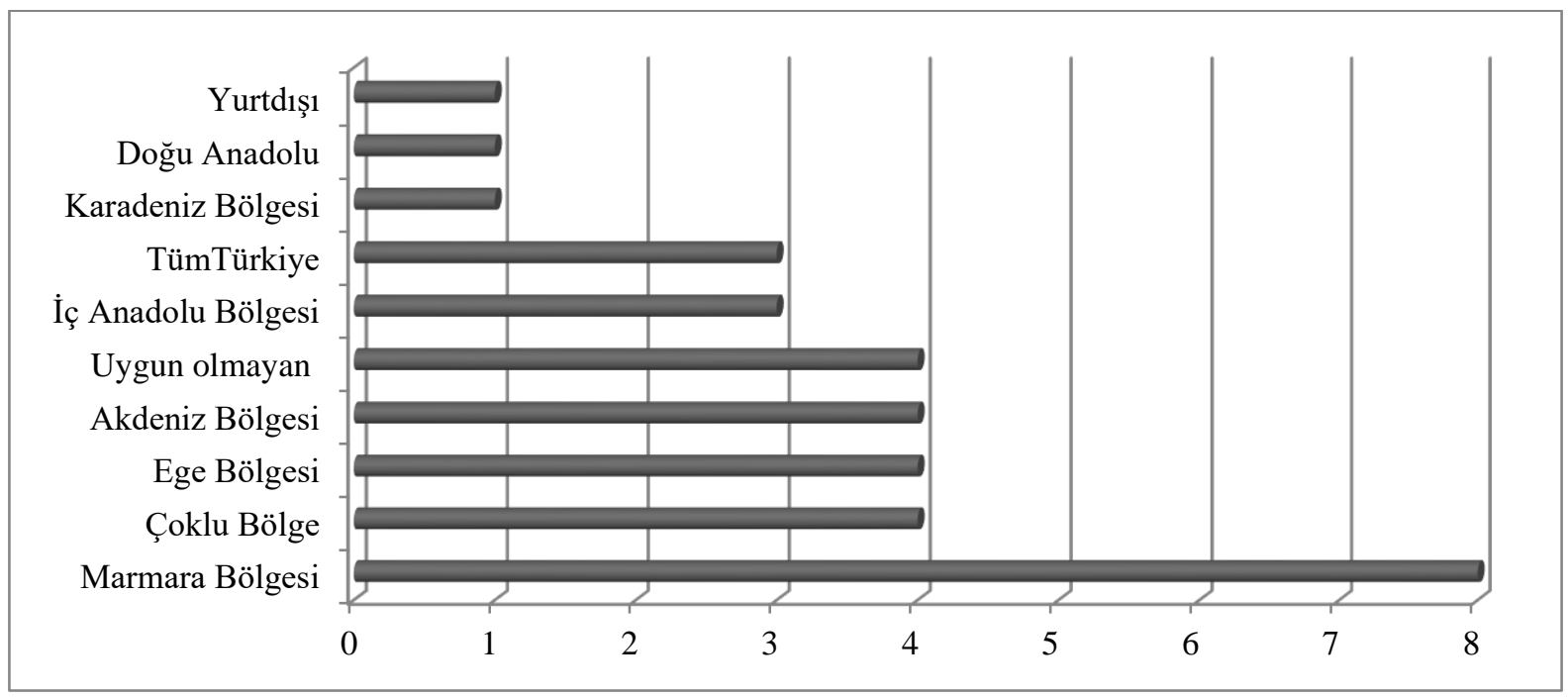

Örneklem büyüklükleri açısından ele alındığında, çalışmaların ağılıklı olarak 1-99 örneklem büyüklüğünde gerçekleştirildiği görülmektedir. Örneklem büyüklüğünün 100 ve altında sayıda olması nicel araştırmalar için yetersiz olarak ifade edilse de incelenenler arasında verinin mülakat ve odak grup gibi tekniklerle toplandığı çalışmalar bulunmaktadır. Ayrıca, örneklem büyüklüğü 200-299 aralığında üç, 300-399 aralığında yedi, 400-499 aralığında ise üç makalenin olduğu anlaşılmıştır. Makalelerin örneklem büyüklüğüne ilişkin detaylı bilgi Grafik 6'da verilmektedir. 


\section{Grafik 6: Makalelerin Örneklem Büyüklüklerine Göre Dağılımı}

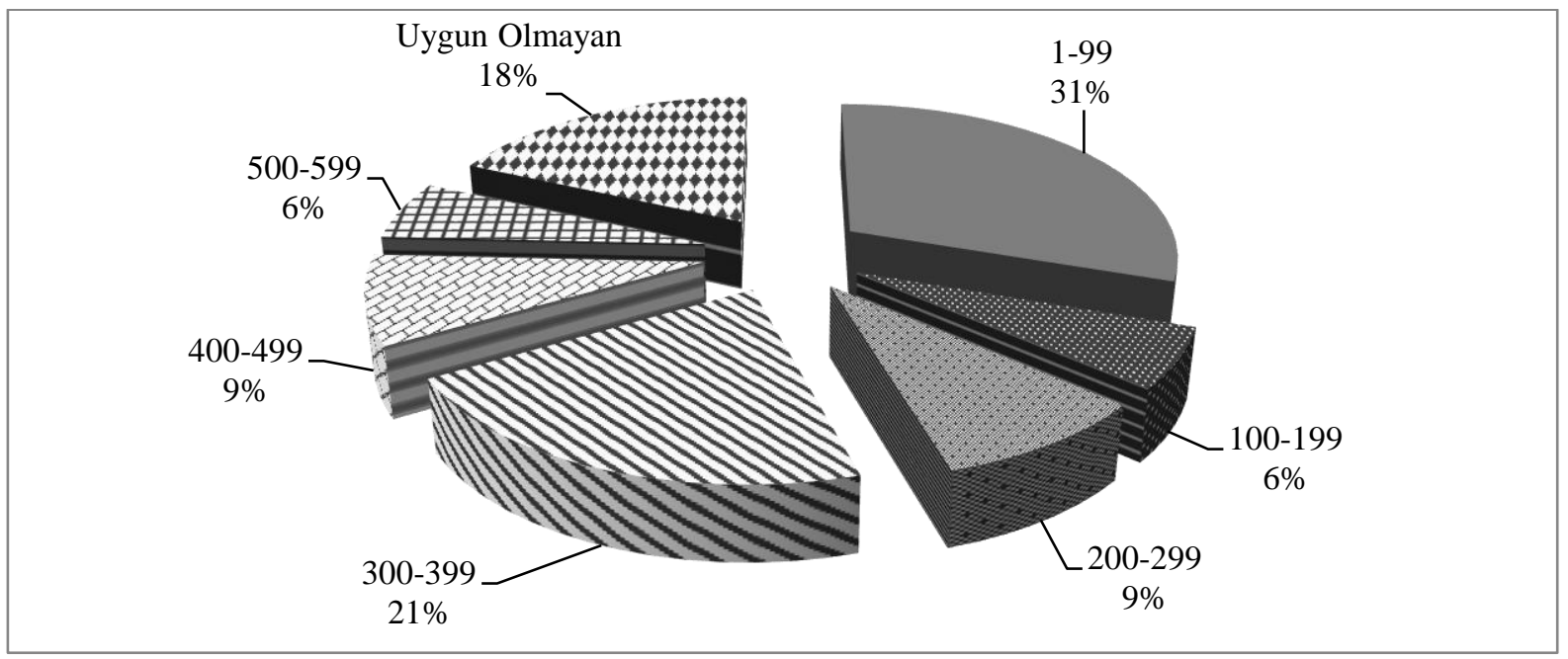

Çalışma kapsamında ele alınan 33 makalede kullanıımış olan veri toplama yöntemleri incelendiğinde, çalışmalarda ağırlıklı olarak anket tekniği ile veri toplanmış olduğu görülmektedir. Çalışmaların \%9'unda mülakat tekniğinden yararlanılmışken, \%9'unda karma teknikler ile veri toplanmıştır (Grafik 7). Turizm alanında gerçekleştirilen bazı bibliyometrik çalışmalarda (Şahin ve Acun, 2015) benzer şekilde anket tekniğinin ağırıkta olduğu sonucuna ulaşılmıştır. Uygun olmayan seçeneği ise çeviri, alanyazın taraması, kavramsal çalışma ve ikincil veriden yararlanılan çalışmaları ifade etmektedir.

\section{Grafik 7: Makalelerin Veri Toplama Yöntemine Göre Dağılımı}

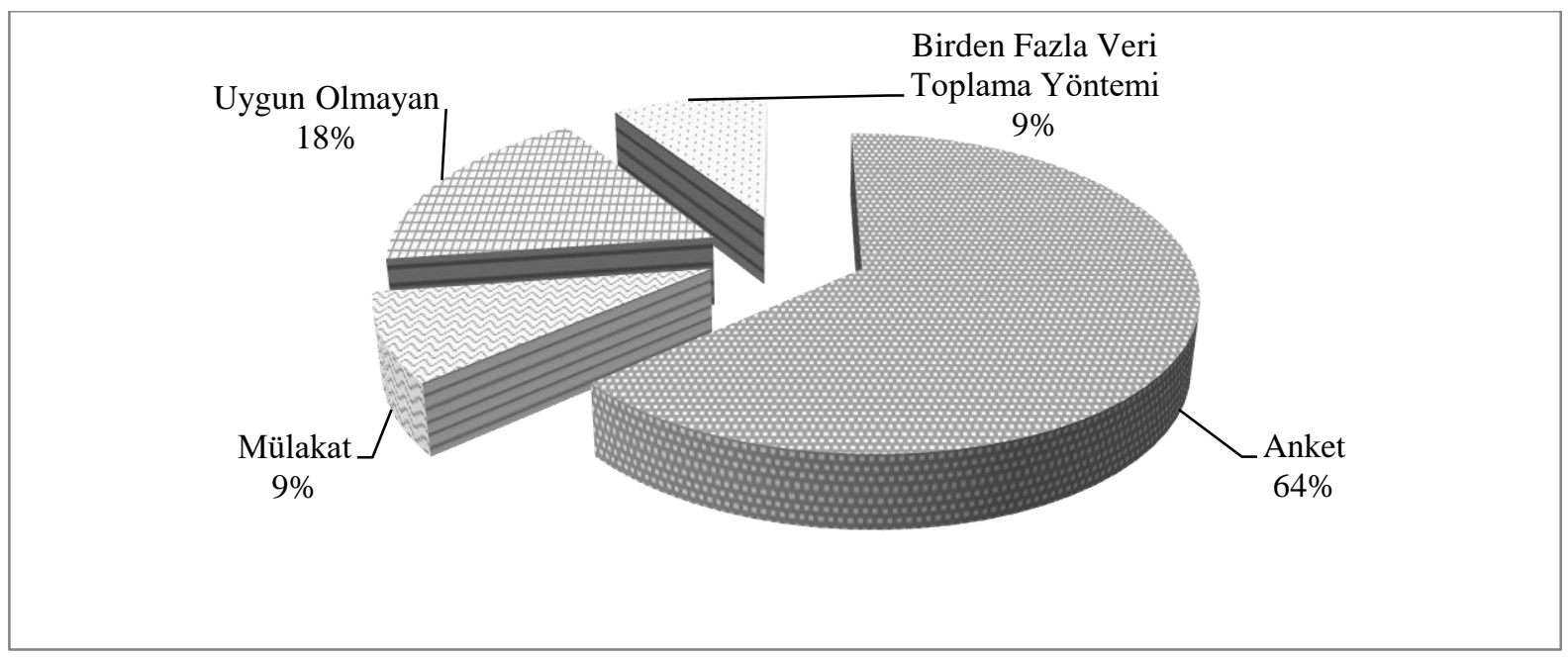

Makalelerde incelenen alt sektörlere bakıldığında, en fazla makalenin konaklama işletmeleri örneğinde gerçekleştirildiği görülmektedir (Grafik 8). İncelenen dergilerde turizm sektörü dışındaki alanlarda da yapılan makalelerin yayınlanmış olduğu görülmüştür. Konaklama işletmelerinden sonra en fazla yüzdeye sahip olan diğer seçeneği sağlık sektörü, imalat sektörü gibi turizm dışı sektörleri içermektedir. Bunun dışında beş çalışma yiyecek ve içecek alanında gerçekleştirilmiştir. İki çalışma farklı destinasyonları konu almakta iken bir çalışma konaklama, seyahat ve yiyecek içecek 
işletmelerini konu almış olmasından dolayı birden fazla alan kategorisi altında sınıflandırılmıştır.

\section{Grafik 8: Makalelerin İncelenen Alanlara Göre Dağılımı}

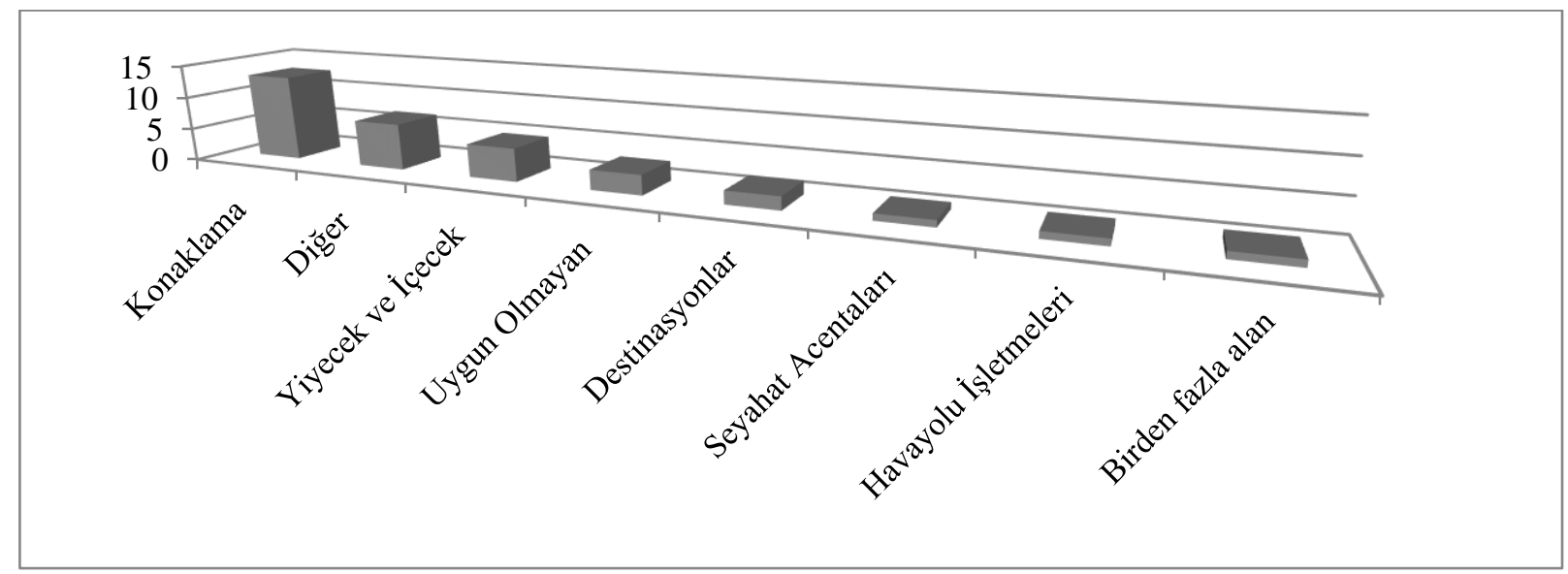

Grafik 9 incelendiğinde, yapılan çalışmaların 11'inde yöneticilerden, altısında çalışanlardan, dördünde birden fazla kitleden ve üçünde tüketicilerden veri toplandığı görülmektedir. Bu bağlamda, inovasyonlar ile ilgili makalelerde verinin çoğunlukla karar verici konumda olmalarından dolayı turizm işletmesi yöneticilerinden ve uygulayıcı konumda olmalarından dolayı ise çalışanlardan toplanmış olduğu görülmektedir. Herhangi bir kategori altında gruplandırılamayan çeviri, alanyazın taraması ve ikincil veri ile gerçekleştirilen çalışmalar yine uygun olmayan kategorisi altında toplanmıştır. Bahsedilenler dışında tüketiciler (turistler de dâhil olmak üzere), öğrenciler ve yerel halkın da hedef kitle olarak belirlendiği çalışmalar bulunmaktadır.

\section{Grafik 9: Makalelerin Verilerin Toplandığı Kitleye Göre Dağılımı}

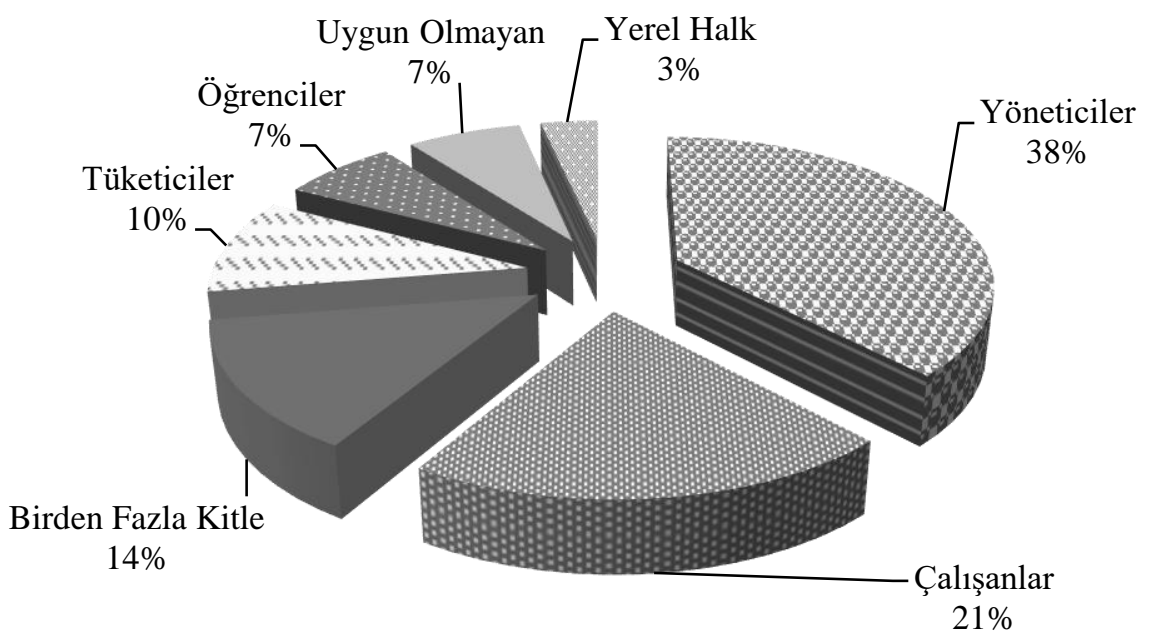

İncelenen çalışmalar analiz yöntemleri açısından incelendiğinde, Grafik 10'da görülebileceği üzere parametrik testlerin parametrik olmayan testlere göre daha sıklıkla kullanıldığı tespit edilmiştir. Leech ve Onwuegbuzie (2002) parametrik olmayan testlerin kullanımının doğru olmaması, hatalı ve geçersiz sonuçlar sağlayabilmesi gibi 
düşüncelerle analizlerde sıklıkla yer verilmediğine işaret etmektedir. Benzer şekilde, bu çalışmada da parametrik olmayan testlerin sınırlı sayıda kullanılmış olduğu görülmektedir (Grafik 10). Bunun yanı sıra, üç çalışmada tanımlayıcı istatistikler aracılığı ile analiz gerçekleştirilmiş iken, bir çalışmada deneysel model benimsenmiş ve duyusal analiz gerçekleştirilmiştir.

\section{Grafik 10: Makalelerin Analiz Yöntemlerine Göre Dağılımı}

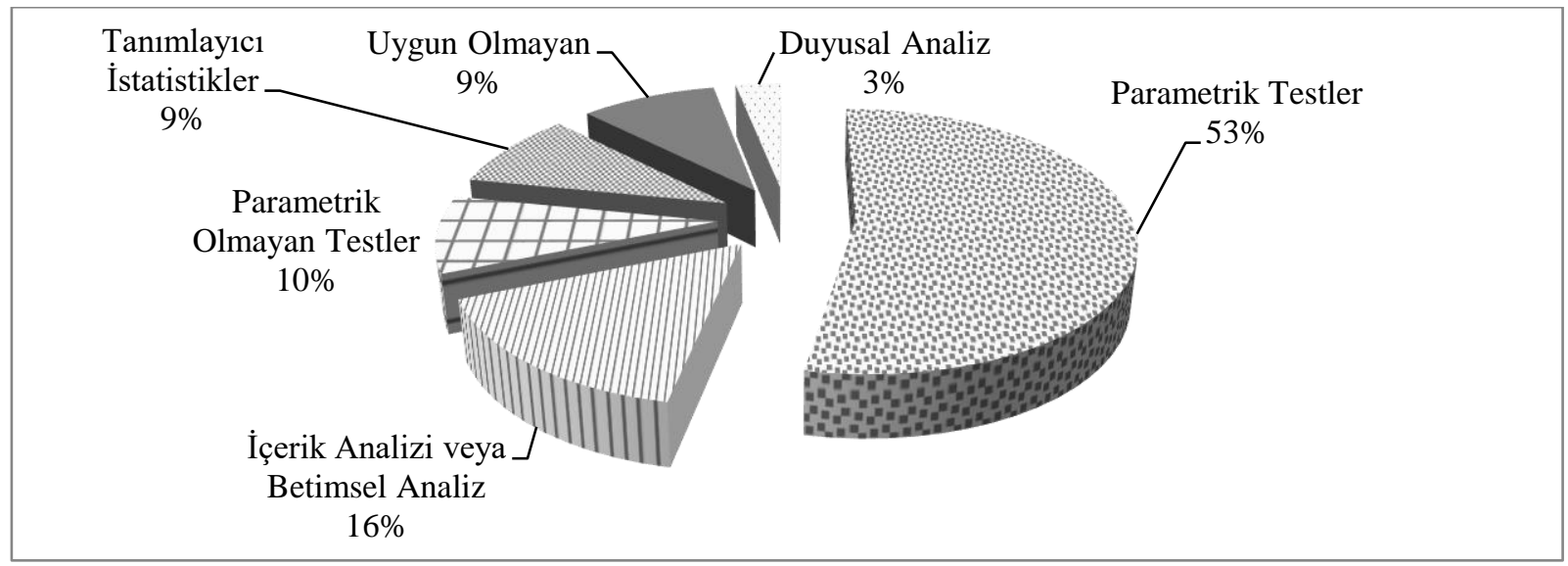

Son olarak, ele alınan çalışmalarda yararlanılan kaynaklar analiz edildiğinde incelenen 33 çalışmada toplamda 1666 kaynaktan yararlanılmış olduğu, bunların 1091'i yabancı, 575'i ise Türkçe kaynaklardan oluştuğu görülmektedir. Kaynakların dağılımı Grafik 11'de gösterilmektedir. Her bir makalenin yararlanmış olduğu toplam kaynak sayısına bakıldığında ise sonuçların 21-60 arasında yoğunlaştığı dikkat çekmektedir.

\section{Grafik 11: Makalelerde Yararlanılan Kaynakların Dağılımı}

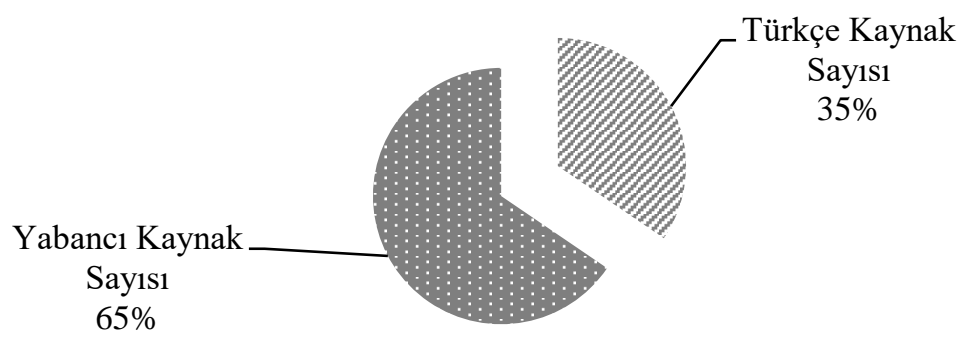

\section{Sonuç ve Öneriler}

Bu çalışma ile inovasyon konusunda çalışacak olan araştırmacılara ve ilgili alanyazına ilişkin bazı çıkarımlarda bulunulmaktadır. Öncelikle, bu çalışma kapsamında akademik yayın yapan turizm dergileri listelenmiştir ki bu yeni araştırmacıların turizm dergilerini tanıması açısından ve makalelerini turizm dergilerine yönlendirmek suretiyle turizm alanyazınına katkı sunmalarını sağlamak adına önemli görülmektedir. Ayrıca turizmde inovasyon konusunda çalışacak olan araştırmacılara özellikle Türkçe kaynaklara ulaşım konusunda makalelerin hangi dergilerde yoğunlaştığını göstermek açısından da önemli bir çıktı sunulduğu düşünülmektedir. Turizmde inovasyon üzerine çalışacak olan 
araştırmacılar, bu konu ile ilgili yapılmış çalışmalarda kullanılan veri toplama teknikleri, örneklem grubu seçimi, kaynak tercihi gibi konularda fikir sahibi olabileceklerdir. Çalışma, akademik turizm dergilerinde Türkçe olarak inovasyon üzerine yapılmış makalelerin bibliyometrik analiz ile değerlendirilmesini esas alması açısından önem taşımaktadır.

Çalışmada, zaman sınırlamasına yer verilmemiş olup, turizm dergilerinde (tüm sayılarda) yayınlanan "inovasyon", "yenilikçilik", "yenilik", "yenileşim", "inovatif" ve "yenilikçi" kavramlarıyla ilgili yapılan makaleler belirli parametreler çerçevesinde incelenmiştir. Bu bağlamda, farklı veri tabanları aracılığıyla taranan toplam 30 akademik turizm dergisinde yayınlanan 33 inovasyon başlıklı makale bu çalışma kapsamında incelenmiştir. Yenilik geliştirmenin ve yenilikçiliğin büyük önem arz ettiği turizm sektöründe yayınlanan çalışmaların turizm dergilerinde sınırlı sayıda olması dikkat çekicidir. İnovasyon kavramı, her sektör için büyüme, rekabet üstünlüğü ve sürdürülebilirlik açısından önem arz etse de özellikle turizm gibi dinamik ve dünyanın her yerinde aynı ürün ve hizmetin talep edilebildiği bir sektörde daha kritik bir öneme sahiptir (Peters ve Pikkemaat, 2005: 1). Her ne kadar Türkçe alanyazında akademik turizm dergileri özelinde inovasyon çalışmaları sınırlı sayıda yapılmış olsa da çalışmaların yapıldığı yıllar incelendiğinde, özellikle 2014 yılından sonra çalışmaların artış gösterdiği görülmektedir.

Akademik turizm dergilerinin bu alanla ilgili yapılan makalelere yer verme durumlarına bakıldığında, toplam 30 turizm dergisinin sadece 13'ünün inovasyonla ilgili makalelere yer vermiş olduğu sonucuna ulaşılmıştır. Konuyla ilgili en fazla sayıda makale yayınlayan üç dergi JOTAGS, Uluslararası Turizm, Ekonomi ve İşletme Bilimleri Dergisi ve SOID'tir.

Çalışmada, makaleleri yayınlanan araştırmacıların çalıştıkları kurumlara göre dağılımında Atatürk Üniversite'sinin 11 araştırmacı ile konuyla alakalı en fazla çalışma yapan yazarların görevli olduğu üniversite olduğu sonucuna ulaşılmıştır. Atatürk Üniversitesi'ni sekiz araştırmacı ile Mersin Üniversitesi izlemektedir. Çalışmaların örneklemi incelendiğinde ise, Marmara Bölgesi'nin sekiz çalışmada örneklem olarak seçilmesi bu bölgenin örneklem olarak en çok tercih edilen destinasyon olduğu sonucunu ortaya koymuştur. Özellikle İstanbul ilinin bu bölgede olması ve nitelikli turizm işletmelerinin büyük çoğunluğunun bu ilde olmasından dolayı Marmara Bölgesi'nin en çok tercih edilen araştırma bölgesi olduğu söylenebilir.

Turizm dergilerinde yayınlanan inovasyon makalelerinin çoğunlukla inovasyon uygulamaları ve bireysel yenilikçilik konularını kapsadığı ortaya çıkmıştır. Bu sonucun ulusal inovasyon çalışmalarında bireysel yenilikçilik çalışmalarının çoğunlukta olduğu sonucuna ulaşan Işık vd. (2018)'ni desteklediği söylenebilir.

Çalışmada ele alınan 33 makalede hangi alt sektörler üzerinde araştırmaların gerçekleştirildiği incelenmiş ve çoğunlukla konaklama işletmelerinin tercih edildiği anlaşılmıştır. Konaklama işletmelerinin çevrimiçi rezervasyon sistemlerinden, tanıtımına; yenilik kararını etkileyen pazar güçlerinden, insan kaynaklarına kadar tüm alanlarının özellikle güncel kavramları takip edebilmesi ve uygulayabilmesi rekabet açısından önem arz ettiği için (Orfila-Sintes ve Mattsson, 2009: 390-391) ve inovasyona yönelik daha fazla çalışma ve faaliyetlerin diğerlerine nazaran ilgili sektörde yaşanıyor olması nedeniyle bu sonucun ortaya çıktığı düşünülmektedir.

Çalışmaların örneklem büyüklükleri incelendiğinde 1-99 arasında yoğunlaştığı görülmektedir. Nicel araştırmalar için bu örneklem büyüklüğü yetersiz olarak görülse de 
(Sekaran ve Bougie, 2016: 264) nitel araştırmalar için bu örneklem büyüklüğünün yeterli sayıda olduğu söylenebilir. Makalelerde verilerin toplandığı kitle incelendiğinde ise çoğunlukla yöneticiler ve çalışanlardan veri toplandığı sonucuna ulaşılmaktadır.

Makalelerde benimsenen araştırma desenleri incelendiğinde nicel araştırmaların sayıca üstün olduğu görülmektedir. Nicel araştırmalarda verilerin genellikle anket tekniğiyle, nitel araştırmalarda ise mülakat tekniği ile toplanmış olduğu bulunan sonuçlar arasındadır. Bu sonuç daha önce turizm alanında gerçekleştirilmiş olan bazı çalışmaların (Aydın, 2017; Demirbulat ve Dinç, 2017; Sünnetçioğlu vd., 2017) sonuçlarını desteklemektedir. Nicel ve nitel yöntemlerin bir arada kullanıldığı karma çalışmaların son zamanlarda artışına rağmen incelenen makalelerin sadece birinde karma yöntemlere yer verilmiştir. Nicel araştırmalarda ağırlıklı olarak parametrik testlerin kullanıldığı da çalışmanın ortaya koyduğu diğer bir bilgidir.

Çalışmada ulaşılan diğer bir sonuç da makalelerde kullanılan kaynak sayılarıdır. Incelenen makalelerde yabancı kaynaklardan daha fazla yararlanıldığı görülmektedir ki bunun makalelerin uluslararası alanyazın incelemesine önem verdikleri şeklinde yorumlanması mümkündür. Daha önce yapılan bazı bibliyometrik çalışmalarda (Çiçek ve Kozak, 2012; Zencir ve Kozak, 2012) da benzer şekilde yabancı kaynak kullanımının Türkçe kaynak kullanımından daha fazla olduğu belirlenmiştir. Araştırmaların çoğunlukla ampirik olup, az sayıda kavramsal çalışmanın gerçekleştirilmiş olduğu da çalışmanın sonuçları arasındadır.

\subsection{Sınırılıklar ve Gelecek Araştırmalar için Öneriler}

Birçok çalışmada olduğu gibi bu çalışmada da birtakım sınırlılıklar bulunmaktadır. Bu sınırlılıkların başında bu çalışma kapsamında sadece akademik turizm dergileri ve bu dergilerde tespit edilmiş inovasyon başlıklı 33 makale incelenmiştir. Ayrıca bu çalışmada sadece Türkçe dilinde yayın yapan akademik turizm dergilerinin taranmış olması bir diğer sınırlılık olarak ifade edilebilir. Bir diğer sınırlıık ise çalışmada sınırlı sayıda parametre kullanılmasıdır. İleriki çalışmalarda özellikle atıf analizi parametresi de eklenerek ilgili alanın bilgi birikimine katkı sağlanabilir. Bununla birlikte ileriki çalışmalarda yabancı dilde yayın yapan akademik turizm dergilerinin ve makalelerinin de incelenmesi önerilmektedir. Ayrıca, gelecekte yapılacak benzer konudaki araştırmaların bu çalışmanın sonuçları ile kıyaslanarak çıkarımlarda bulunulması ile ilgili alanyazının gelişimine katkı sağlanabileceği ifade edilebilir.

\section{Kaynakça}

Aldebert, B., Dang, R. J. ve Longhi, C. (2011), Innovation in the Tourism Industry: The Case of Tourism, Tourism Management, 32(5), ss. 1204-1213.

Ayaz, N. ve Türkmen, B. M. (2018), Yöresel Yiyecekleri Konu Alan Lisansüstü Tezlerin Bibliyometrik Analizi, Gastroia: Journal of Gastronomy and Travel Research, 2(1), ss. 22-38.

Aydın, B. (2017), Yükseköğretim Kurulu Tez Merkezinde (YÖKTEZ) Yiyecek İçecek İşletmeciliği Alanında Kayıtlı Bulunan Tezlerin Bibliyometrik Analizi, Disiplinlerarası Akademik Turizm Dergisi, 2(1), ss. 23-38.

Başkale, H. (2016), Nitel Araştırmalarda Geçerlik, Güvenirlik ve Örneklem Büyüklüğünün Belirlenmesi, Dokuz Eylül Üniversitesi Hemşirelik Fakültesi Elektronik Dergisi, 9(1), ss. 23-28.

Bozok, D., Kılıç, S. N. ve Özdemir, S. S. (2017), Bibliometric Analysis of Rural Tourism on Tourism Literature, Journal of Human Sciences, 14(1), ss. 187-202. 
Camisón, C. ve Monfort-Mir, V. M. (2012), Measuring Innovation in Tourism from Schumpeterian and the Dynamic-Capabilities Perspective, Tourism Management, 33(4), ss.776-789.

Cevizkaya, G., İlsay, S. ve Avcıkurt, C. (2014), Turizm Alan Yazınında Engelliler ile İlgili Çalışmaların Bibliyometrik Profili 2000-2013, Gazi Üniversitesi Turizm Fakültesi Dergisi, (2), ss. 101-108.

Cheng, M., Edwards, D., Darcy, S. ve Redfern, K. (2018), A Tri-Method Approach to a Review of Adventure Tourism Literature: Bibliometric Analysis, Content Analysis, and a Quantitative Systematic Literature Review, Journal of Hospitality \& Tourism Research, 42(6), ss. 997-1020.

Çakıcı, A. C., Yıldırım, O. ve Karacaoğlu, S. (2013), Ulusal Turizm Kongreleri Bildirilerinin Bibliyometrik Profili, 14.Ulusal Turizm Kongresi, ss. 5-8, Ankara: Detay Yayıncılık:

Çalhan, H. (2018), "İnovasyon", İçinde K. Karamustafa (Editör), Yiyecek ve İçecek Yönetimi, ss. 547-579, Ankara: Detay Yayıncılık.

Çiçek, D. ve Kozak, N. (2012), Anatolia: Turizm Araştırmaları Dergisi'nde Yayımlanan Hakem Denetimli Makalelerin Bibliyometrik Profili, Türk Kütüphaneciliği, 26(4), ss. 734-756.

Çiftçi, M., Tozlu, E. ve Akçay, A. (2014), Drucker Perspektifinde İnovasyonun İşletmelerin Gelişimi Üzerine Etkisi: Girişimci İşletme, Visionary EJournal/Vizyoner Dergisi, 5(10), ss. 76-85.

Demir, Ö. (1995), Joseph A. Schumpeter: Hayatı, Eserler ve Katkıları, Ankara Üniversitesi Siyasal Bilgiler Fakültesi Dergisi, 1(50), ss. 155-172.

Demirbulat, Ö. G. ve Dinç, N. T. (2017), Sürdürülebilir Turizm Konulu Lisansüstü Tezlerin Bibliyometrik Profili, Seyahat ve Otel İşletmeciliği Dergisi, 14(2), ss. 20-30.

Ekonomik İşbirliği ve Kalkınma Örgütü (OECD) (2005), Oslo Kılavuzu, 3. Baskı, Paris.

Erdem, B., Gökdeniz, A. ve Met, Ö. (2011), Yenilikçilik ve İşletme Performansı İlişkisi: Antalya'da Etkinlik Gösteren 5 Yıldızlı Otel İşletmeleri Örneği, Dokuz Eylül Üniversitesi Iktisadi ve Idari Bilimler Fakültesi Dergisi, 26(2), ss. 77-112.

Evren, S. ve Kozak, N. (2014), Bibliometric Analysis of Tourism and Hospitality Related Articles Published in Turkey, Anatolia, 25(1), ss. 61-80.

Fairthorne, R. A. (2005), Empirical Hyperbolic Distributions (Bradford-Zipf-Mandelbrot) For Bibliometric Description and Prediction, Journal of Documentation, 61(2), ss. 171-193.

Glanzel, W. (2003), Bibliometrics as a Research Field a Course on Theory and Application of Bibliometric Indicators, Course Handouts.

Halpern, N. (2010), Marketing Innovation: Sources, Capabilities and Consequences at Airports in Europe's Peripheral Areas', Journal of Air Transport Management, 16(2), ss. 52-58.

Hjalager, A. M. (1997), Innovation Patterns in Sustainable Tourism: An Analytical Typology, Tourism Management, 18(1), ss. 35-41.

Hjalager, A. M. (2002), Repairing Innovation Defectiveness in Tourism, Tourism Management, 23(5), ss. 465-474.

Hjalager, A. M. (2010), A Review of Innovation Research in Tourism, Tourism Management, 31, ss.1-12.

Işık, C. ve Keskin, G. (2013), Bilgi Ekonomilerinde Rekabet Üstünlüğü Oluşturulması Açısından İnovasyonun Önemi, Atatürk Üniversitesi İktisadi ve Idari Bilimler Dergisi, 27(1), ss.41-57.

Işık, C. ve Türkmendağ, T. (2016), Atatürk Üniversitesi Turizm Fakültesi Öğrencilerinin Bireysel Yenilikçilik Algılarının Belirlenmesi, Gazi Üniversitesi Turizm Fakültesi Dergisi, 1(1), ss. 70-99.

Işık, C. ve Barlak, S. (2018), Hotel Managers' Perception of Green Innovation: The Case of Istanbul, Journal of Tourism Intelligence and Smartness, 1(1), ss. 14-26. 
Işık, C., Akoğul, E., Taş, S., Uyrun, A., Hajiyeva, T., Turan, B. ve Dırbo, A.H. (2018), Turizm ve İnovasyon İlişkisi: Literatür Taraması, Journal of Tourism Intelligence and Smartness, 1(2), ss. 34-74.

Jacob, M., Tintoré, J., Aguiló, E., Bravo, A. ve Mulet, J. (2003), Innovation in the Tourism Sector: Results from a Pilot Study in the Balearic Islands, Tourism Economics, 9(3), ss. 279-295.

Karagöz, D. ve Kozak, N. (2014), Anatolia Turizm Araştırmaları Dergisi'nin Bibliyometrik Analizi: Araştırma Konuları ve Kurumlar Arası İş Birliğinin Sosyal Ağ Analizi ile İncelenmesi, Türk Kütüphaneciliği, 28(1), ss. 47-61.

Kızılırmak, İ. ve Albayrak, A. (2013), İnovasyon Örneği Olarak Moleküler Mutfağın İstanbul'daki Restoran İşletmelerinde Uygulanmasına Yönelik Bir Araştırma, 14. Ulusal Turizm Kongresi, ss. 55-72, Ankara: Detay Yayıncılık.

Koç, E. ve Boz, H. (2014), Triangulation in Tourism Research: A Bibliometric Study of Top Three Tourism Journals, Tourism Management Perspectives, 12, ss. 9-14.

Kozak N. (1994), Anatolia: Turizm Araştırmaları Dergisi'nde Yayımlanan Yazılar Üzerine Bir Inceleme, Anatolia: Turizm Araştırmaları Dergisi, 5(3): 22-33.

Kozak N. (1995), Türkiye'de Yayımlanan Turizm Konulu Makaleler Üzerine Bir İnceleme, Anatolia: Turizm Araştırmaları Dergisi, 6(1): 62-72.

Kozak N. ve İçöz O. (1999), Turizm İşletmeciliği Dergisi'nin Turizm Literatürüne Katkısı Hakkında Bir İnceleme, Anatolia: Turizm Araştırmaları Dergisi, 10(2), ss. 9-17

Köseoğlu, M. A., Şehitoğlu, Y. ve Parnell, J. A. (2015), A Bibliometric Analysis of Scholarly Work in Leading Tourism and Hospitality Journals: The Case of Turkey, Anatolia, 26(3), ss. 359-371.

Köseoğlu, M. A., Şehitoglu, Y., Ross, G. ve Parnell, J. A. (2016), The Evolution of Business Ethics Research in the Realm of Tourism and Hospitality, International Journal of Contemporary Hospitality Management, 28(8), ss. 1598-1621.

Leech, N. L. ve Onwuegbuzie, A. J. (2002), A Call for Greater Use of Nonparametric Statistics, Technical Report, US Dept. Education.

Lemon, M. ve Sahota, P. S. (2004), Organizational Culture as a Knowledge Repository for Increased Innovative Capacity, Technovation, 24(6): 483-498.

Martínez-Pérez, A., Elche, D. ve Garcia-Villaverde, P. M. (2019), From Diversity of Interorganizational Relationships to Radical Innovation in Tourism Destination: The Role of Knowledge Exploration, Journal of Destination Marketing \& Management, 11, ss. 80-88.

Martin-Rios, C. ve Ciobanu, T. (2019), Hospitality Innovation Strategies: An Analysis of Success Factors and Challenges, Tourism Management, 70, ss. 218-229.

Niñerola, A., Sánchez-Rebull, M. V. ve Hernández-Lara, A. B. (2019), Tourism Research on Sustainability: A Bibliometric Analysis, Sustainability, 11(5), ss. 1377-1394.

Nordli, A. J. (2018), Information Use and Working Methods as Drivers of Innovation in Tourism Companies, Scandinavian Journal of Hospitality and Tourism, 18(2), ss. 199-213.

Orfila-Sintes, F. ve Mattsson, J. (2009), Innovation Behaviour in the Hotel Industry, Omega, 37(2), ss. 380-394.

Ottenbacher, M. ve Gnoth, J. (2005), How to Develop Successful Hospitality Innovation', Cornell Hotel and Restaurant Administration Quarterly, 46(2), ss. 205-22.

Özel, Ç. H. ve Kozak, N. (2012), Turizm Pazarlaması Alanının Bibliyometrik Profili (20002010) ve Bir Atıf Analizi Çalışması, Türk Kütüphaneciliği, 26(4), ss. 715-733.

Palmer, A. L., Sese, A. ve Montano, J. J. (2005), Tourism and Statistics: Bibliometric Study 1998-2002, Annals of Tourism Research, 32(1), ss. 167-178.

Peters, M. ve Pikkemaat, B. (2005), Innovation in Hospitality and Tourism, New York: Routledge.

Pirnar, I., Bulut, C. ve Eris, E. D. (2012), Improving the Performance and Competitiveness of Tourism Establishments by means of Innovation Trends and 
Applications, Enlightening Tourism: 1st International Conference Competition and Innovation in Tourism: New Challenges in an Uncertain Environment, ss. 133-142, Naples.

Pivcevic, S. ve Pranicevic, D. G. (2012), Innovation Activity in the Hotel Sector: The Case of Croatia, Ekonomska Istrazivanja - Economic Research, 25(1), ss. 337-363.

Presenza, A., Petruzelli, A. M. ve Sheehan, L. (2019), Innovation through Tradition in Hospitality: The Italian case of Albergo Diffuso, Tourism Management, 72, ss. 192-201.

Pritchard, A. (1969), Statistical Bibliography or Bibliometrics, Journal of Documentation, 25(4), ss. 348-349.

Ruhanen, L., Weiler, B., Moyle, B. D. ve McLennan, C. L. J. (2015), Trends and Patterns in Sustainable Tourism Research: A 25-year Bibliometric Analysis, Journal of Sustainable Tourism, 23(4), ss. 517-535.

Sánchez, A. D., Del Río, M. D. L. C. ve García, J. Á. (2017), Bibliometric Analysis of Publications on Wine Tourism in the Databases Scopus and WOS, European Research on Management and Business Economics, 23(1), ss. 8-15.

Schumpeter, J. A. (1964), Business Cyds: A Theoretical, Historical and Statistical Analysis or the Capitalist Process, New York: McGrawHill Book Company.

Schumpeter, J. A. (2003), Capitalism, Socialism and Democracy, London: The Taylor \& Francis e-Library.

Sekaran, U. ve Bougie, R. (2016), Research Methods for Business: A Skill-Building Approach, New York: Wiley.

Sünnetçioğlu, A., Yalçınkaya, P., Olcay, M. ve Mercan, Ş. O. (2017), Turizm Alanında Yazılmış Olan Gastronomiye Illişkin Tezlerin Bibliyometrik Profili, Journal of Tourism and Gastronomy Studies, 5(2), ss. 345-354.

Şahin, S. ve Acun, A. (2015), Turist Rehberliği Alanının Bibliyometrik Profili Ulusal Turizm Kongreleri Bildirileri, Balıkesir Üniversitesi Sosyal Bilimler Enstitüsü Dergisi, 18(34), ss. 213-234.

Tayfun, A., Küçükergin, F. N., Aysen, E., Eren, A. ve Özekici, Y. K. (2016), Turizm Alanında Yazılan Lisansüstü Tezlere Yönelik Bibliyometrik Bir Analiz, Gazi Üniversitesi Turizm Fakültesi Dergisi, (1), ss.50-69.

Tayfun, A., Ülker, M., Gökçe, Y., Tengilimoğlu, E., Sürücü, Ç. ve Durmaz, M. (2018), Turizm Alanında Yiyecek ve İçecek ile İlgili Lisansüstü Tezlerin Bibliyometrik Analizi. Journal of Tourism and Gastronomy Studies, 6(2), ss. 523-547.

Temizkan, P., Çiçek, D. ve Özdemir, C. (2015), Bibliometric Profile of Articles Published on Health Tourism, Journal of Human Sciences, 12(2), ss. 394-415.

Tidd, J., Bessant, J. ve Pavitt, K. (2005), Managing Innovation: Integrating Technological, Market and Organisational Change, Chichester: Wiley.

Türk Dil Kurumu 'İnovasyon' www.tdk.gov.tr/index.php?option=com gts\&arama=gts\&guid=TDK.GTS.5c821d 9c65b709.02717011 (08.01.2019).

Vila, M., Enz, C. ve Costa, G. (2012), Innovative Practices in the Spanish Hotel Industry, Cornell Hospitality Quarterly, 53(1), ss. 75-85.

Walle, A. H. (1997), Quantitative Versus Qualitative Tourism Research, Annals of Tourism Research, 24(3), ss. 524-536.

Wallin, J. A. (2005), Bibliometric Methods: Pitfalls and Possibilities, Basic \& Clinical Pharmacology \& Toxicology, 97(5), ss. 261-275.

Yıldııım, A. ve Şimşek, H. (2008). Sosyal Bilimlerde Nitel Araştırma Yöntemleri. Ankara: Seçkin.

Yılmaz, G. (2017), Gastronomi ve Turizm İlişkisi Üzerine Bir Değerlendirme, Seyahat ve Otel İşletmeciliği Dergisi, 14(2), ss. 171-191. 
Zencir, E. ve Kozak, N. (2012), Sosyal Bilimler Enstitü Dergilerinde Yayımlanan Turizm Makalelerinin Bibliyometrik Profili (2000-2010), VI. Lisansüstü Turizm Öğrencileri Araştırma Kongresi, ss. 673-682.

\section{EK 1. Bu Bibliyometrik Çalışma Kapsamında Değerlendirilen Makaleler}

Albayrak, A. (2017), Restoran İşletmelerinin Yenilik Uygulama Durumları: İstanbul'daki Birinci Sınıf Restoranlar Üzerine Bir Çalışma, Journal of Tourism and Gastronomy Studies, 5(3), ss. 53-73.

Arsıan F. ve Çakmak A.F. (2019), Yiyecek-İçecek Çalışanlarının Yenilikçi İş Davranışı ile İlişkisinde Dönüşümcü Lider ve Demografik Bazı Değişkenlere Göre Farklılığının İncelenmesi, Türk Turizm Araştırmaları Dergisi, 3(3), ss. 220-235.

Ayaz N. ve Türkmen B. M. (2018), Yenilik Yönetimi Uygulamaları Üzerine Butik Otel İşletmelerinde Bir Araştırma, Journal of Recreation and Tourism Research, 5(2), ss. 24-32.

Bağıran Özşeker, D., Kurgun, H. ve Kurgun O. (2018), Otel İşletmelerinde İş Modeli İnovasyonunda Stratejik Bir Yaklaşım Olarak İnovasyon Radarı: Swissotel Büyük Efes İzmir Örnek Olay Çalışması, Journal of Tourism and Gastronomy Studies, 6(3), ss. 133-170.

Bal, M., Yıldırım, M., ve Sönmezdağ, A. S. (2019), İnovatif Yaklaşımlarla Osmanlı Meyveli Baklavasının Gastronomiye Kazandırıması, Turizm Akademik Dergisi, 6(2), ss. 215-226.

Bayındır, M. S. ve Demir, M. (2019), Otel İşletmelerinde Mutfak Şeflerinin Yenilikçi Davranışlarını Etkileyen Faktörlerin Analizi: Antalya Örneği, Journal of Tourism and Gastronomy Studies, 7(3), ss. 1689-1710.

Cankül, D. (2019), İşletmelerde Yenilik Uygulamaları: Restoran İşletmeleri Örneği, Gastroia: Journal of Gastronomy and Travel Research, 3(2), ss.225-240.

Ceylan, U. ve Karaman, S. (2017), Kurumsal İtibar Oluşturma Sürecine Müşteri Şikâyet Yönetimi, İnovasyon ve Ögrrenmenin Etkisi: Seyahat Acentaları Üzerine Bir Araştırma, Uluslararası Global Turizm Araştırmaları Dergisi, 1(2), ss. 85-106.

Çakıcı, A. C., Şimşek Evren, E. ve Evren, S. (2019), Akademisyen Kültür Turistlerinin Yenilik Arama Düzeyleri ve Kültür Destinasyonu Tercihleri, Türk Turizm Araştırmaları Dergisi, 3(3), ss. 271-282.

Çetin, A. ve Topaloğlu, C. (2018), Otel İşletmelerinde Cameron-Quinn Örgüt Kültürü Tiplerinin Yenilikçiliğe Etkisi, Journal of Tourism and Gastronomy Studies, 6(2), ss. 457-473.

Çetin, S. A. ve Şahin, B. (2018), Aşçıların Beş Faktör Kişilik Özellikleri İle Bireysel İnovasyon Algısı İlişkisi, Journal of Tourism and Gastronomy Studies, 6(4), ss. 419-447.

Çetintürk, İ., Adıgüzel, O. ve Demir, C. (2016), Sürdürülebilir Rekabetçi Üstünlük Kaynağı Olarak Yenilik Yeteneği: Beş Yıldızlı Konaklama İşletmeleri Üzerine Bir Araştırma, Anatolia: Turizm Araştırmaları Dergisi, 27(1), ss. 25-42.

Çöp, S. ve Topcu, M. (2019), Sosyal Sermayenin Hizmet İnovasyonu Üzerine Etkisinde Bilgi Paylaşımının Aracılık Rolü: Otel İşletmeleri Üzerine Bir Araştırma, Turizm Akademik Dergisi, 6(1), ss. 31-48.

Dölarslan, E. Ş. (2018), Marka İnovatifliği, Algılanan Kalite ve Marka Sadakati Arasındaki İlişki, International Journal of Tourism, Economics and Business Sciences, 2(2), ss. 86-96.

Duygun, A. ve Yücel, M. F. (2018), Yolcu Tercihlerinde Havayolunun Algılanan Yenilikçilik Düzeyinin Rolü Üzerine Bir Araştırma, Seyahat ve Otel İşletmeciliği Dergisi, 15(2), ss. 443-460. 
Doğan, H. ve Aktan, V. (2018), Mutfakta Kadının Rolü ve Yenilikçi Yaklaşımına Yönelik Muğla İ Merkezinde Bir Araştırma, Journal of Tourism and Gastronomy Studies, 6(2), ss. 60-73.

Eraslan, H., Bulu, M. ve Bakan, İ. (2008), Kümelenmeler ve İnovasyona Etkisi: Türk Turizm Sektöründe Uygulamalar, Seyahat ve Otel İşletmeciliği Dergisi, 5(3), ss. $15-29$.

Güler, O., Akdağ, G., Çakıcı, C. ve Benli, S. (2015), Turizmi Değiştiren 100 Yenilik, Anatolia: Turizm Araştırmaları Dergisi, 26(2), ss. 290-317.

Günsel, A. ve Pelenk, S. E. (2017), Yenilikçi İnsan Kaynakları Yönetimi Uygulamalarının Yenilik Odaklı Bir Kültür Oluşturmadaki Rolü, International Journal of Tourism, Economics and Business Sciences, 1(2), ss. 57-68.

Işık, C. ve Barlak, S. (2018), Otel Yöneticilerinin Yeşil İnovasyon Algıları: İstanbul İli Örneği, Journal of Tourism Intelligence and Smartness, 1(1), ss. 14-26.

Işık, C., Küçükaltan, E. G., Çelebi, S. K., Çalkın, Ö., Enser, İ. ve Çelik, A. (2019), Turizm ve Girişimcilik Alanında Yapılmış Çalışmaların Bibliyometrik Analizi. Güncel Turizm Araştırmaları Dergisi, 3(1), ss. 119-149.

Işık, C. ve Hajiyeva, T. (2019), Bireysel Yenilikçilik ve Algılanan Örgütsel Destek Düzeyi İlişkisi: İstanbul Otelleri Örneği, Güncel Turizm Araştırmaları Dergisi, 2(2), ss. 206227.

Işık, C., Akoğul, E., Taş, S., Uyrun, A., Hajiyeva, T., Turan, B. ve Dırbo, A. H. (2018), Turizm ve İnovasyon İlişkisi: Literatür Taraması, Journal of Tourism Intelligence and Smartness, 1(2), ss. 34-74.

Işık, C. ve Türkmendağ, T. (2016), Atatürk Üniversitesi Turizm Fakültesi Öğrencilerinin Bireysel Yenilikçilik Algılarının Belirlenmesi, Gazi Üniversitesi Turizm Fakültesi Dergisi, 1(1), ss.70-99.

Kahvecioğlu, J., Bekar, A. ve Kılıç, B. (2019), Z Kuşağının Gastronomi Turizmine İlişkin Tutumlarının Yenilik Arayışı Kapsamında Değerlendirilmesi, Journal of Tourism and Gastronomy Studies, 7(4), ss. 2855-2872.

Kale, E. Y. ve Birdir, S. S. (2010), Otel İşletmelerinde Yenilikçi Hizmetler, Seyahat ve Otel Iş̧letmeciliği Dergisi, 7(2), ss. 30-40.

Kale, E. (2019), Proaktif Kişilik ve Kontrol Odağının, Kariyer Tatmini ve Yenilikçi İş Davranışına Etkisi, Journal of Tourism Theory and Research, 5(2), ss. 144-154.

Mercan, G. ve Çetin, A. K. (2018), Hibe Desteklerinin Firma İnovasyonuna Etkisi: Türkiye Örneği, International Journal of Tourism, Economics and Business Sciences, 2(2), ss. 65-71.

Öztürk, A. ve Günsel, A. (2018), Hizmet Yenilikçiliği Kavramı ve Sağlık Sektöründe Hizmet Yenilikçiliğinin Gelişimi, International Journal of Tourism, Economics and Business Sciences, 2(2), ss. 402-418.

Sahilli Birdir, S. ve Kale, E. Y. (2014), Restoran İşletmelerinde Yenilik Uygulamaları: Mersin ve Adana Örneği, Seyahat ve Otel İşletmeciliği Dergisi, 11(3), ss. 57-72.

Süt, E. ve Çetin, A. K. (2018), İnovasyon Göstergesi Olarak İnovasyon Endeksleri, International Journal of Tourism, Economics and Business Sciences, 2(2), ss. 299-309.

Topsakal, Y. ve Yüzbaşıŏlu, N. (2018), Turizm İşletmelerinin Özelliklerine Göre Sosyal İnovasyon Algı Farkları, Journal of Tourism Intelligence and Smartness, 1(1), ss. 27-46.

Yavuz, M. C. (2019), Akıllı Destinasyon: Turizm, İnovasyon, Girişimcilik ve Çözüm Bekleyen Konular, Journal of Tourism Theory and Research, 5(2), ss. 203-211.

Zengin, B. ve Dursun, C. (2017), Otel İşletmelerinde Uygulanan İnovatif Faaliyetlerin Rekabet Avantajı Üzerine Etkileri: Doğu Marmara Örneği, Turizm \& Araştırma Dergisi, 6(2), ss. 38-58. 